\title{
LAND TENURE LEGISLATION IN TIMOR-LESTE
}

\section{Bernardo Almeida}

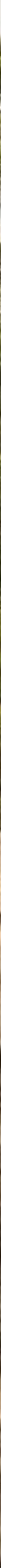

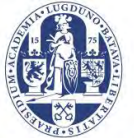

Universiteit Leiden

Faculty of Law

Van Vollenhoven Institute

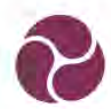

The Asia Foundation 


\section{LAND TENURE LEGISLATION}

\section{IN TIMOR-LESTE}

Bernardo Almeida

March 2016 


\section{Land Tenure Legislation in Timor-Leste}

Report author: Bernardo Almeida

Published by: The Asia Foundation

Photo Credit: Bernardo Almeida

(C) Copyright 2016: Bernardo Almeida and The Asia Foundation

\section{Acknowledgements}

The author would like to express his gratitude to Adriaan Bedner and Laura Ogden for their comments, contributions and revisions. The author also would like to thank and acknowledge the contributions of Anjet Lanting, Guilherme Almeida, Hugo Oliveira, João Albuquerque, Lene Ostergaard, Lindsey Greising, Miguel Lemos, and Ricardo Cunha.

Special thanks go to The Asia Foundation for the publication of this research.

\section{About The Asia Foundation}

The Asia Foundation is a non-profit international development organization committed to improving lives across a dynamic and developing Asia. Informed by six decades of experience and deep local expertise, our programs address critical issues affecting Asia in the 21st century-governance and law, economic development, women's empowerment, environment, and regional cooperation. In addition, our Books for Asia and professional exchange programs are among the ways we encourage Asia's continued development as a peaceful, just, and thriving region of the world.

Headquartered in San Francisco, The Asia Foundation works through a network of offices in 18 Asian countries and in Washington, DC. Working with public and private partners, the Foundation receives funding from a diverse group of bilateral and multilateral development agencies, foundations, corporations, and individuals. In 2015, we provided more than $\$ 95$ million in direct program support and distributed textbooks and other educational materials valued at over $\$ 10$ million.

To learn more, visit our website: www.asiafoundation.org. 


\section{DISCLAIMER:}

The views and opinions expressed in this article are those of the author and do not necessarily represent those of The Asia Foundation or its funders. 


\section{TABLE OF CONTENTS:}

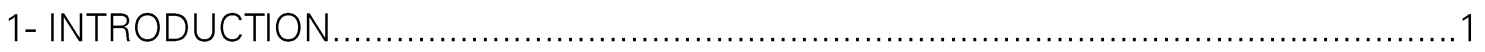

1.1 - A Short Note on Legal Sources.................................................................... 2

2- HISTORICAL OVERVIEW

3- LAND GOVERNANCE AFTER THE REFERENDUM ..................................... 4

4- GOVERNMENT INSTITUTIONS RESPONSIBLE FOR THE FORMAL

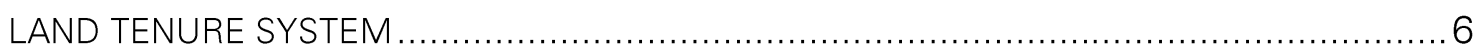

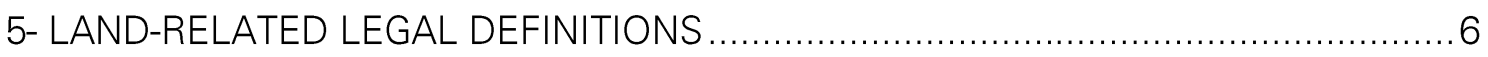

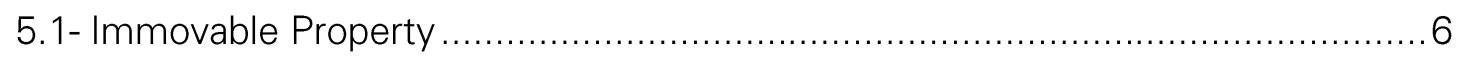

5.2- Public and Private Domain of the State......................................................... 7

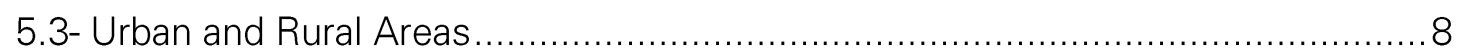

6- WHAT KIND OF LAND RIGHTS EXIST AND WHO CAN HAVE THEM? .................. 8

6.1- Are Pre-Independence Land Rights Still Valid? .............................................. 8

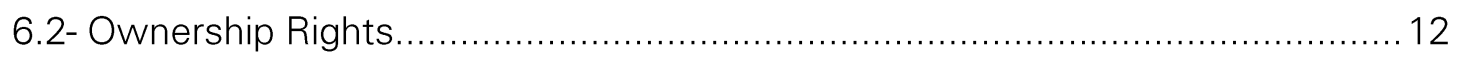

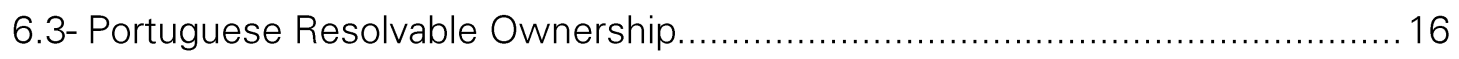

6.4- Land Rights Other Than Ownership ......................................................... 17

6.5- Lease Contracts of State and Abandoned Land............................................ 19

6.6- Lease Contracts Between Private Parties........................................................ 21

6.7- Legal Protection of the Holder of a Lease Contract ....................................... 21

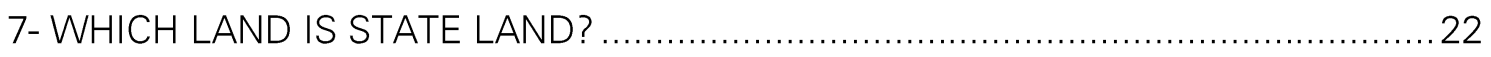

7.1- How the Law Defines State Land? ........................................................... 22

7.2- Does Abandoned Property Belongs to the State? ..................................... 24

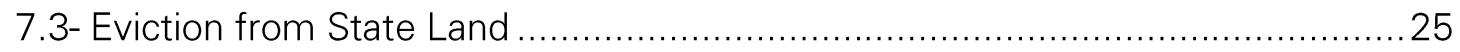

8- DOES THE STATE RECOGNIZE CUSTOMARY LAND RIGHTS? .......................... 27

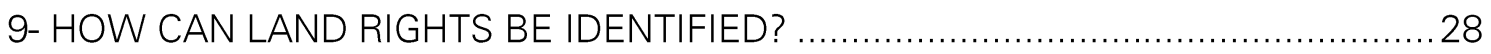

9.1- The Process Established by Law 1/2003 ................................................... 28

9.2- The Process Established by Decree-Law 27/2011 ......................................... 31

10- LEGAL MECHANISMS FOR ACQUISITION AND LOSS OF LAND RIGHTS ...........35 


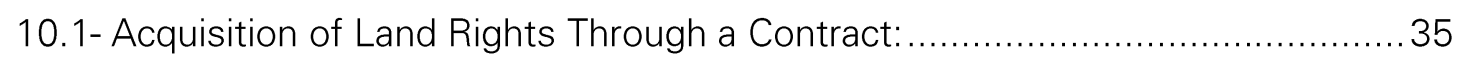

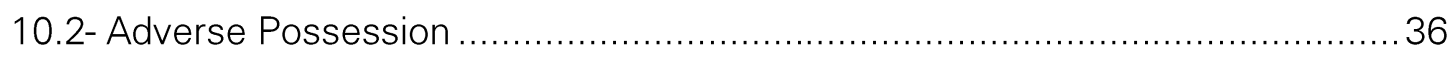

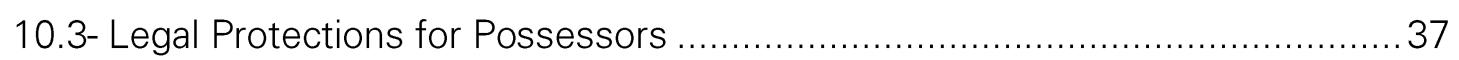

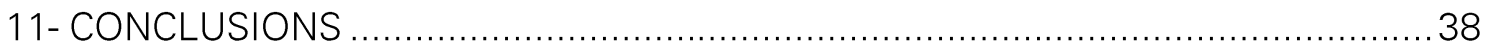

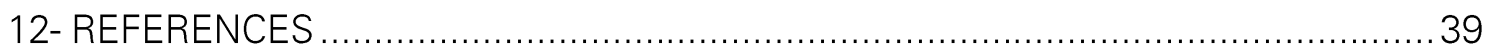

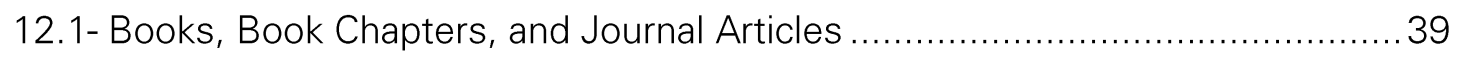

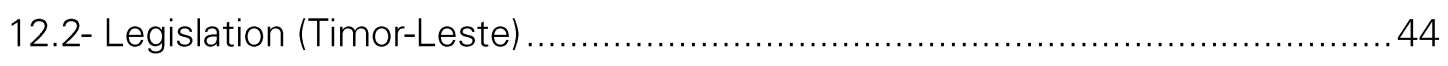

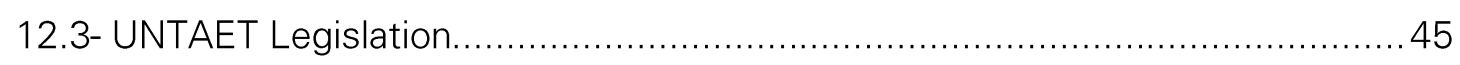

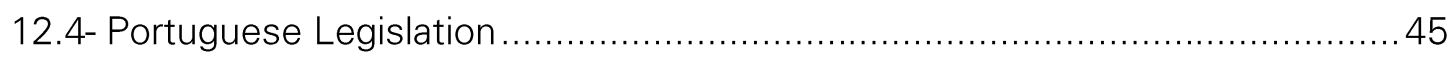

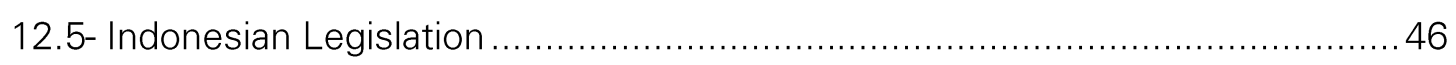

12.6- Legislation from Other Countries............................................................. 46

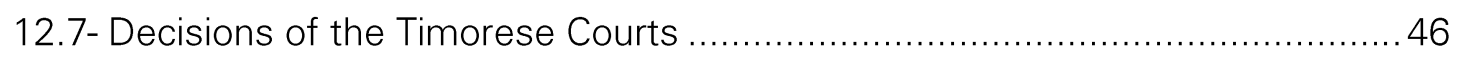

12.8- Decisions of the Portuguese Courts ....................................................... 47

12.9- Decisions of Indonesian Courts ............................................................ 47

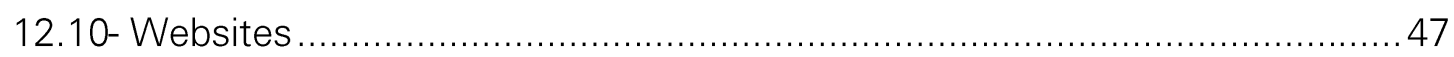

12.11- Newspaper Articles and Media Releases ............................................... 48 


\title{
Land tenure legislation in Timor-Leste
}

\author{
Bernardo Almeida'
}

\section{1- INTRODUCTION}

The establishment of a formal land tenure system in Timor-Leste has been one of the most daunting challenges for the country since its independence. ${ }^{2}$ The post-colonial and post-conflict history has left a complex environment of conflicting land claims to which no solution has yet been found. Additionally, the customary land tenure systems that de facto rule most of the country have been more and more confronted by external interference caused by post-independence infrastructure and investment projects. While there has been considerable academic work undertaken regarding land tenure in Timor-Leste, a systematic legal analysis of the legislation regulating land tenure that has been approved since independence is still lacking.

The purpose of this article is to contribute to a better understanding of the legislation currently in force in Timor-Leste concerning (or regulating) land tenure. ${ }^{3}$ For the past six years, three land-related draft laws (the Special Regime for the Determination of Immovable Property Ownership, the Expropriation Law, and the Immovable Property Fund) have been debated in council of ministers and parliament; but as they have not yet been enacted, they are beyond the scope of this study. This paper also does not analyse Law 3/2014 and the following regulations regarding the Special Zone of Social Market Economy of Oe-Cusse Ambeno, and Decree-Law 36/2014 regarding land acquisitions for the Suai Supply Base. Both of these topics deserve to be analysed in a separate study.

This paper starts with an historical overview of Timor-Leste, which is fundamental to an understanding of the current land tenure situation in the country. Next, the analysis of land tenure legislation includes both land-related legal definitions and a study of different land rights in Timor-Leste and who can have them. Subsequently, the paper looks at the

\footnotetext{
1 This paper draws on the professional experience of the author in Timor-Leste, including a semester as a lecturer in property rights and introduction to private law at the National University of Timor-Leste, and five years as a legal adviser for the Ministry of Justice of Timor-Leste in matters concerning land legislation. The paper also draws on the academic research of the author as a PhD candidate at Leiden University (Netherlands), researching land tenure in Timor-Leste. For this paper 34 decisions of the Timorese Court of Appeal and 12 from district courts were also analysed. The author may be contacted at the following email address: bernardoribeirodealmeida@gmail.com

2 While some people point to the 20 of May 2002 as the day of independence, it is argued by others that independence started with the proclamation of independence from Portugal on the 28 of November 1975, and that 2002 was when international recognition was obtained (see article 1.2 of the Constitution). For the sake of this paper, and not taking any position on this controversy, we will use the expression 'independence' to refer the 20 of May 2002.

3 In the context of Timor-Leste, the definitions of 'land' and 'property' can raise difficulties. For the sake of this paper, unless otherwise stated, the expressions 'land', 'property' and 'asset' will be used interchangeably, following the definition of the Civil Code. More detail about this definition is provided below.

By 'land tenure,' the author means the socially recognized power of a person, a group of persons or the state to control a certain parcel of land, to the full or partially exclusion of others. Land tenure is regulated by social ordering mechanisms that can be designated as 'land tenure systems', which categorize and regulate the different land rights. These systems can be created by the state or other sources of authority such as customary authorities, and different land tenure systems can compete, coexist .or reinforce one another. Throughout this paper, 'land tenure legislation' refers to the state rules that attempt to create a new, or formalize an already existing, land tenure system (the 'formal land tenure system'). Land tenure systems based on custom regulate what will be designated as 'customary land rights'. The term 'customary' or 'custom' will be used to refer to social regulatory practice created and followed by a certain group.
} 
definition of state land, ${ }^{4}$ which relates to the subsequent topic: the recognition of customary land rights. Finally, this analysis debates the existing processes to identify land rights and the legal mechanisms to acquire and be disposed of those rights.

\section{1 - A Short Note on Legal Sources}

The Timorese legal doctrine concerning land, built on court decisions and academic research, is still limited. Additionally, most legislation has been drafted by international consultants, both from civil and common law backgrounds, bringing their own national legal concepts and doctrines that are at times difficult to integrate into the Timorese legal system and difficult to translate into the official languages. Consequently, as described below, the concepts used in Timorese law are fluid and at times unclear, which complicates a legal analysis.

The Portuguese and some Tetun versions of the Timorese legislation mentioned in this paper can be found in the Timorese Official Journal (Jornal da República). ${ }^{5}$ An important feature of the post-independence Timorese legal system, essential to an understanding of this paper, is that it received as subsidiary legislation the Indonesian laws in force before 25 October 1999 and those approved by the United Nations Transitional Administration in East Timor (UNTAET, 1999-2002). However, in practice, Indonesian laws are infrequently invoked. Both the executive and the courts have insufficient knowledge of the Indonesian legal system; further, this system is often inadequate for the Timorese reality and institutions. Therefore, the executive and the courts tend to rely on laws approved since independence or to wait for the approval of new laws (with some exceptions).

\section{2- HISTORICAL OVERVIEW}

The Portuguese arrived on the island of Timor in the early sixteenth century, but during the first few centuries of engagement with the island the colonial authorities were focused on trading, and therefore did not invest much effort in extending strong administrative control over the eastern territory of Timor. ${ }^{6}$ However, in the last decades of the nineteenth century, the economic focus on trade shifted to cash-crop agriculture, especially coffee, creating the necessity to assert stronger control over the territory in order to obtain access to the land and labour essential for large-scale agricultural

\footnotetext{
${ }^{4}$ In English legal texts, it is common to find references to 'government land' instead of 'state land' to refer to the land that is part of the assets of a country. In this paper, the expression 'state land' will be used to refer to those assets. It is true that a considerable percentage of the state land can be controlled by the government, but this control should not be mixed with the ownership of the land. In fact, state land can be under control of state bodies other than government. ${ }^{5}$ Available online at http://jornal.gov.tl/. The English versions of UNTAET and some Timorese legislation can be found at http://jornal.gov.t//lawsTL/index-e.htm. In this paper, the quotes in English from legislation have been retrieved from this website, but when not correctly translated, the quotes were retranslated by the author from the original Portuguese version.

${ }^{6}$ Since the sixteenth century, the Portuguese and the Dutch disputed the control over the island of Timor. The dispute was settled through the Lisbon Treaty of 1859, which divided the island into two territories - West Timor for the Dutch and East Timor (Timor-Leste) for the Portuguese (including the enclave of Oe-Cusse Ambeno). However, the boundary of the territory was only formally established in 1914 (Krieger, 1997: xix).
} 
production. The Portuguese administration over Timor-Leste was briefly interrupted by the violent Japanese occupation during the Second World War (1942-1945). ${ }^{7}$ After the end of the war, Portugal regained control of Timor-Leste, making use of the disruption created by the Japanese invasion to further spread its administrative structures throughout the colony. Nevertheless, the control of the Timorese population and territory by the Portuguese colonial administration was weak and mainly focused on a few areas of agricultural interest. Furthermore, the resilience of the Timorese social structures allowed them to maintain their main characteristics, only superficially adapting to the imposed colonial administrative structures (Taylor, 1991: 15). ${ }^{8}$

The Carnation Revolution on 25 April 1974 ended 41 years of dictatorship in Portugal and was the starting point for the process of decolonization of all Portuguese colonies, including Timor-Leste. At the same time as debates started regarding the future of the colony, UDT (União Democrática de Timor-Leste), a newly formed political party, attempted to outmanoeuvre another new Timorese political party, FRETILIN (Frente Revolucionária de Timor-Leste), by attempting a coup against the Portuguese administration. FRETILIN's counter-offensive quickly evolved into a short but brutal civil war in which FRETILIN assumed de facto control of the territory. ${ }^{9}$ The possible end of the Portuguese rule of Timor-Leste and the fear of the emergence of a communist regime fuelled Indonesia's ambition to annex the Timorese territory. Under the impending threat of an Indonesian invasion, on the 28 November FRETILIN unilaterally declared the independence of Timor-Leste from Portugal. Indonesia brutally invaded Timor-Leste just ten days later, invoking an integration request by political parties UDT, Apodeti, Trabalhista and KOTA.

During the first years after the Indonesian invasion, FRETILIN's armed resistance in the mountains of Timor-Leste was progressively suppressed by military offensives and strategies of the Indonesian troops, such as the destruction of food crops and the forced resettlement in 'strategic camps' of those people that could provide support to the resistance fighters. ${ }^{10}$ Starvation, illness, death, and misery were widespread during the first years of the Indonesian occupation. As a result of a weakening of the resistance forces in the early 1980s, people were progressively allowed to leave the camps and return to their villages or new resettlement areas. However, brutality and repression continued to characterize the Indonesian administration during the following decades. ${ }^{11}$

Increasing international pressure and the end of Suharto's regime in Indonesia in 1998 led to the independence referendum of 30 August 1999, in which the Timorese

\footnotetext{
7 It is estimated that between 40,000 to 60,000 Timorese died as a result of the Japanese invasion (CAVR, 2005: part 3, 10).

${ }^{8} \mathrm{~A}$ more detailed and nuanced vision of the influence of the Portuguese administration can be found in Fitzpatrick et al., 2012: $36-40$

9 Between 1,500 and 3,000 people were killed and between 10,000 and 30,000 thousand were displaced to West Timor as consequence of this civil war (CAVR, 2005: part 3, 43-44).

10 It is estimated that 372,921 Timorese were displaced to these strategic camps in the first years of the occupation (Fitzpatrick, 2002: 135).

11 In the words of the CAVR report, "[Indonesian security forces] consistently resorted to killings and disappearances during the whole period of its occupation of Timor-Leste. These (...) killings and disappearances had an overall strategic purpose, namely that of eliminating opposition to the occupation by terrorising the general population. (...) The killings committed by the Indonesian security forces had a particularly horrific character. The methods used ranged from death by severe deprivation in a prison cell to public executions committed using the most extreme brutality (...)," (CAVR, 2005: part 7.2,6-7).
} 
overwhelmingly voted for independence. In response to this result, pro-Indonesia militia, in collaboration with the Indonesian military forces, unleashed widespread destruction, death and displacement, which was only halted by the intervention of the United Nations peacekeeping force INTERFET (International Force for East Timor) in September of the same year. On 25 October 1999, the United Nations Transitional Administration in East Timor (UNTAET) was established to provisionally administer the territory. ${ }^{12}$ The governing of the country was handed over to elected national institutions on 20 May 2002. Since then, the country has been trying to rebuild state institutions and address the severe social and economic problems provoked by years of conflict. The state vulnerabilities were highlighted during the political crisis of 2006. The dismissal of 591 soldiers from the army (F-FDTL) were cause of protests that quickly became violent and out-of-control. Order was only restored after external intervention. The events of 2006 resulted in the deaths of 37 people, the displacement of 150,000, and the destruction of 1,650 buildings. As a consequence of the crisis, the Prime Minister Mari Alkatiri resigned (United Nations 2006). Fourteen years after independence, Timorese society still faces poverty, unemployment and scarcity of basic services, particularly in rural areas (Sahin, 2010; Kingsbury, 2014: 195-196).

\section{3- LAND GOVERNANCE AFTER THE REFERENDUM}

One of the biggest challenges faced by UNTAET was land governance. UNTAET Regulation No. 1999/1 gave to this administration a clear mandate to administer all movable and immovable property in Timor-Leste previously belonging to Indonesia, as well as property abandoned after the referendum (article 7.1 and 7.2). The difficulty of administering land tenure in a post-conflict environment was further complicated by the debate about to what extent UNTAET could enact new legislation concerning land tenure (Thomson, 2003: 11). UNTAET was aware of the urgency of establishing a Land Commission or any other legal solution that could quickly clarify and allocate land rights (Thomson 2003; Plessi \& Leckie, 2000: 28; Morrow \&White, 2002: 42); but any decision on this matter was always halted by strong opposition on the part of the Timorese political elite (Gorjão, 2004: 1059-1060). On 25 October 2000 the Transitional Cabinet decided to defer any decision on land claims and disputes to a Timorese-elected government. ${ }^{13}$ As a result, UNTAET made minimal use of its legislative powers where land is concerned, approving only some transitory regulations, and focussing most of its efforts on the administration of state land and abandoned land. Most of UNTAET's land administration was based on a policy, The Guidelines for the Administration of Public and Abandoned Property by District Administrations, which was applied almost as law, but was never converted into any kind of formal legislation (Thomson, 2003: 11, 18).

12 The United Nations Security Council, acting under Chapter VII of the Charter of the United Nations, through Resolution 1272 (1999) of 25 October 1999, mandated UNTAET with legislative and executive powers, which also included the administration of justice (article 1).

${ }^{13} \mathrm{http}: / /$ reliefweb.int/report/timor-leste/untaet-daily-briefing-25-oct-2000. See also article 16.4 of Law 1/2003. 
The legal and practical difficulties of land tenure experienced by the UNTAET administration were then inherited after independence by the succeeding Timoreseelected governments. Despite the approval of some land-related legislation, a national land policy addressing the problems caused by the transition of Portuguese and Indonesian legal systems and land policies, has never been established. Of all of the land-related debates, the one about establishing a land tenure policy is the most controversial, with various interest groups - the state, customary-based land claimants, ${ }^{14}$ Portuguese title holders, ${ }^{15}$ Indonesian title holders, ${ }^{16}$ and long- and short-term land possessors-using different sources of legitimacy to compete for the tenure and/or formal recognition of their tenure over the same plots of land. The confusion is further augmented by opportunistic claims to land, ${ }^{17}$ facilitated by the destruction of virtually the entire Indonesian land titles registry. ${ }^{18}$ The unclear land tenure situation is further complicated by squatters occupying several plots of land, ${ }^{19}$ especially in urban areas. ${ }^{20}$ These squatters are usually among the poorest of the population; they dispense no legal recognition of their land tenure, and no national legislation protects them against eviction. In rural areas the problems are generally less acute, but most of the rural population depends on subsistence agriculture, and any threat to their land tenure can seriously risk their livelihoods. ${ }^{21}$ The lack of efficient government and judicial institutions, ${ }^{22}$ combined with growing pressure for access land tenure for state and private investments ${ }^{23}$ further complicates the current land tenure situation.

\footnotetext{
${ }^{14}$ As the numbers below show, few Timorese ever had their land rights formalized by the Portuguese and Indonesian administrations. According to Nixon, only 3 percent of the rural area of the country was ever transferred from customary tenure into formalized land titles (Nixon, 2009: 3).

15 Authors report that between 2,709 and 2,850 land titles were issued by the Portuguese administration. It is also mentioned that around 55 percent of those titles are in Dili district and 15 percent in coffee plantation areas (quoting other authors, Yoder, 2005: 301). The official journal in which Portuguese land titles were publicized can be found at http://btimor.iict.pt/

16 Fitzpatrick states that until 1996, the Indonesian administration issued 34,965 land titles in Timor-Leste (Fitzpatrick, 2002: 94). Quoting other authors, Fitzpatrick also mentions that, by 1998, the Indonesian administration had issued 44,091 titles. Anecdotal evidence indicates that a high percentage of these land titles were issued in favour of non-Timorese.

17 For example, claimants that voluntarily sold their land during the Indonesian or Portuguese administrations and now reclaim the land; use of forged documents to obtain any kind of tenure recognition.

${ }^{18}$ There are stories indicating that some land rights records were saved from destruction. Allegedly, the book containing the registry of Dili land titles was saved by the Indonesian head of the land titles office but was never returned to TimorLeste (Fitzpatrick, 2002: 7). Some other land records were saved by the Timorese staff of the Indonesian land titles office that were organized in shifts to protect these documents (Thomson, 2003: 10). Supposedly in Baucau, land records were saved in a secret cave, but never returned (/dem). Whatever Indonesian land registries may have survived the wave of destruction in 1999, they are not publically available, organized, nor have they been systematically used.

19 The word 'squatters' will be used to refer to those cases in which the people using the land do not have a socially or legally recognized right over the land they use, and where their occupation of the land is in conflict with the legal rights of the state or a third party.

${ }^{20}$ Land tenure problems in urban areas are further increased by the current rural exodus, especially to the urban area of Dili. In 2004, 11 percent of the Timorese population (101,551 people) lived in the urban area of Dili. In 2010 this number grew to 18 percent of the Timorese population (192,652 people), an increase of almost 90 percent in six years (Highlights of the 2010 Census. Calculations made by the author).

${ }^{21}$ According to the 2010 Census, 70.4 percent $(750,323$ of $1,066,409)$ of the population live in rural areas. The TimorLeste Household Income and Expenditure Survey 2011 shows that the average monthly income in rural areas is $\$ 32$ USD (\$24 USD in the district of Oe-Cusse Ambeno)

22 During the Indonesian administration, most senior civil servants were from Indonesia and left Timor-Leste after the violence that followed the 1999 referendum. No Timorese judges or public prosecutors were ever sworn in during the Indonesian administration. Consequently, the existing Timorese lawyers had no experience of working in the judicial system. The search for qualified lawyers was done by word-of-mouth and by dropping leaflets from airplanes (Chesterman, 2005: 85). Currently only four courts serve the 13 districts. There are 40 judges, 40 prosecutors, 36 public defenders, 113 justice officials (bailiffs), 9 translators and 54 administration staff, and around 84 registered lawyers in all of Timor-Leste (JSMP, 2014: 25; IPAC, 2015: 13).

${ }^{23}$ By 'access to land tenure,' the author means the possibility of obtaining physical control of a certain parcel of land.
} 


\section{4- GOVERNMENT INSTITUTIONS RESPONSIBLE FOR THE FORMAL LAND TENURE SYSTEM}

The Ministry of Justice (MoJ) is the entity responsible for the cadastre and registration of immovable property, as well as managing state land (articles 22.1 [i] and 22.1 [l] of Decree-Law 06/2015 and article 2 [l] and 2 [m] of Decree-Law 25/2015). Within the MoJ, the National Directorate for Land, Property and Cadastral Services (Direcção Nacional de Terras, Propriedades e Serviços Cadastrais, or DNTPSC) ${ }^{24}$ is responsible for these tasks (article 18 of Decree-Law 25/2015). The DNTPSC is comprised of a National Directorate and thirteen District Offices - one in each of the districts. ${ }^{25}$ Decree-Law 06/2015 also creates the position of Secretário de Estado for Land and Property, which is responsible for overseeing the DNTPSC on the behalf of the Minister of Justice (article 4 [g]) ${ }^{26}$

Following the approval of Decree-Law 4/2014 regarding the administrative predeconcentration, the government plans to delegate several powers to the district level, including powers regarding evictions, managing a cadastre, registration and representation of the state in claiming state land (articles 6.2 [c] 11.1 [a]vii, 15.1 [q] and 15.3). However, each of these powers is dependent on specific delegation by the MoJ (article 15.4). This law creates new district structures led by a district manager, who is considered a representative of the government at the district level (article 12.1). At the time of writing, no district managers had been appointed, despite the schedule that was established in the annex of the law. Furthermore, there are plans to change the approach regarding the administrative pre-deconcentration. In practice the district offices of the DNTPSC are still in charge of all of the above-mentioned tasks.

\section{5- LAND-RELATED LEGAL DEFINITIONS}

All of the above-mentioned institutions have to work with land-related legal definitions. Analysing these definitions is particularly important because, as mentioned above, the legal concepts used in Timorese law are fluid and at times unclear, complicating the interpretation and implementation of legislation.

\section{1- Immovable Property}

Articles 1.1 and 1.2 of Law 1/2003 (Juridical Regime of Immovable Property) first attempted to define 'immovable property' (bens imóveis) as 'all the urban and rural real estate, as well as their integral parts'. Article 195 of the Civil Code provides a more detailed definition of immovable property that, in short, can be defined as the land and all things that are permanently connected to it, including constructions, trees and

\footnotetext{
24 This national directorate was previously designated as National Directorate of Land and Property (in Portuguese Direcção Nacional de Terras e Propriedades - DNTP) - Article 12 of Government Decree 3/2003.

${ }^{25}$ Articles 3.1, 7 and 14 of Ministerial-Decree 035/2009 that establishes the Organic Law of DNTPSC. The districts are now called 'municipalities'.

${ }^{26}$ Secretário de Estado is a political position within the government, subordinated to a Minister or directly to the PrimeMinister. This position was first created in 2012 by the $V$ Constitutional Government (article 3.2 [d] of Decree-Law 41/2012)
} 
water. ${ }^{27}$ Article 2 (e) of Decree-Law 27/2011 (Regime for Regulating Immovable Property in Undisputed Cases) established the same definition of immovable property, referring directly to the Civil Code.

This definition conflicts with a common view among Timorese that allows a separation of the owner of land from the owner of trees, constructions or plantations on the land (Urresta \& Nixon, 2004b: 74; Yoder, 2003: 6). In the words of Nixon, "there is broad acceptance nationally of the concept that individuals may have rights to features [attachments] geographically situated upon the land parcels of other individuals." (Urresta \& Nixon, 2004a: 31). ${ }^{28}$ While the author is unaware of specific cases, this difference between the legal regime and the informal concept of immovable property has great potential for causing misunderstandings and conflicts (see also Sousa, 2005: 4). The Civil Code establishes some mechanisms that can be used in these cases, such as surface rights, but they dependent on the knowledge and will of the involved parties (see section 6.4).

\section{2- Public and Private Domain of the State}

Timorese law establishes two different categories of state land. Articles 3 and 4 of Law $1 / 2003$ distinguish between public and private domain of the state. Some of the state land is classified as public domain, with the objective of creating a special and more protective regime for the areas that, due to their importance, should be always under the control of the state and be ruled by a special legal regime. ${ }^{29} \mathrm{~A}$ classic example of a public domain area in other countries is the coast line. ${ }^{30}$ All the state land that is not part of the public domain of the state is considered private domain of the state, and is under the same legal regime as any land belonging to private persons (e.g., an urban office building that is owned by the state). ${ }^{31}$

\footnotetext{
27 The Civil Code was approved in 2011 by Law 10/2011. For the sake of this paper, 'Law 10/2011' will be used to refer to the 19 articles that regulate the approval of the Civil Code, and 'Civil Code' will be used to refer to all the articles that compose it. The Civil Code is virtually the same as the Portuguese Civil Code, only differing in a few provisions such as customary marriage and timeframes for adverse possession. The Timorese Civil Code is mentioned at several points in this paper, but a deeper understanding of this comprehensive piece of legislation requires the study of other sources.

${ }^{28}$ Regarding concrete examples of horizontal separation of land and trees, see for instance D'Andrea, 2003.

${ }^{29}$ As comparative examples see for instance article 99 of the Brazilian Civil Code; and article 339 of the Spanish Civil Code.

30 The coast line as part of the public domain is one of the current gaps in the Timorese legislation. As analysed below, while the law establishes the distinction of public and private domain of the state, it does not clearly define which land belongs to each one of these types of state land. Article 27 of Decree-Law 19/2004 establishes that the commercial lease of beach areas to private parties for special and limited use will be regulated in specific legislation (which has never been approved). Articles 4 and 5 of Decree-Law 3/2003 that created the Ports Authority (APORTIL) established some specific areas of 'APORTIL jurisdiction', and consider the ports and docks inside those areas as part of the public domain of the state, if not privately owned. Taking into consideration the definition of state land established in article 4.1 (a) of Law $1 / 2003$, it is important to know what was established in the Portuguese law before the Indonesian invasion. The Legislative Diploma No. 865 of 25 September 1971 was the last piece of Portuguese legislation establishing limits to the coast line. According to articles 2.1 (g) and 2.1 (h), a strip of land 80 meters wide, counted from the highest mark of hightide, around any bay and estuary was considered as public domain of the state. Indonesian legislation received in TimorLeste should also be considered. Articles 13 and 14 of the Presidential Decree 32/1990 established a protected area of 100 meters from the coast line. It is not clear if this protected area must be considered as part of the public domain of the state. Article 521 of the Indonesian Civil Code determined that beaches are property of the state, but such provision was revoked in 1960, with the approval of the Indonesian Agrarian Law (BAL). Nevertheless, remains unclear which, if any, of these piece of legislation are applicable, and in practice they are never referred to by state officials.

31 Besides the lease of state land regulated by Decree-Law 19/2004 (see section 6.5) no other regulation of the state private domain has yet been approved.
} 
However, the wording used in article 3.1 of Law $1 / 2003$ to define public domain is rather confusing, saying that the "immovable property that is outside of legal commerce and is, by nature, not suitable to individual appropriation is part of the public domain." The text of this article seems to be an erroneous adaptation of a common provision existing in the Civil Code of other Lusophone countries, which determines what kinds of goods cannot be transacted or owned by privates: the property that is classified as public domain; and the things that, due to their nature, cannot be individually owned (e.g., the air). ${ }^{32}$ An equivalent provision was later adopted in article 193.2 of the Timorese Civil Code and article 2(f) of Decree-Law 27/2011. The definition of public domain established in the Civil Code prevails, since it is the last one approved. However, no legislation clarifying which property is classified as public domain and its regime has yet been approved. ${ }^{33}$

\section{3- Urban and Rural Areas}

Articles 1.3 to 1.7 of Law 1/2003 classify urban and rural immovable property, based on the location of the property. ${ }^{34}$ However, the regulations mentioned in these articles necessary for the delimitation of urban and rural areas, have not yet been approved. A different classification of urban and rustic immovable property - based on the prevalence or lack of constructions on the land - was later established by article 195.2 of the Civil Code. The Civil Code does not clarify if it repeals the previous classification of urban and rural land, or if this classification is still applicable for the purposes of Law 1/2003.

\section{6- WHAT KIND OF LAND RIGHTS EXIST AND WHO CAN HAVE THEM?}

\section{1- Are Pre-Independence Land Rights Still Valid?}

A first important question is to determine whether the ownership and other land rights acquired by Timorese nationals and foreigners during the Portuguese and Indonesian administrations are still valid, or whether independence wiped out all previous land rights given by the state to individuals. ${ }^{35}$

As Ederington summarized, in the unclear waters of international law states have consistently supported the legal doctrine that protects acquired rights in cases of

\footnotetext{
32 For instance, this provision can be found in article 100 of the Brazilian Civil Code and article 202.2 of the Portuguese Civil Code.

${ }^{33}$ The text of Law 1/2003 debated in parliament mentioned roads, beaches, lakes, rivers and underground minerals as part of public domain, but such provision was removed from the final text. There is legislation for some specific cases: Decree-Law 3/2003 established some ports as part of the public domain of the state. Article 10.1 of Decree-Law 2/2003 established that the roads that are included in the 'National Road Plan' are part of the public domain (however, this plan has never been approved). Article 2 of Decree-Law 3/2006 mentions national airports and aerodromes as part of the public domain of the state.

34 The distinction between urban and rural areas was relevant for the concession of benefits for investors through Laws $4 / 2005$ and 5/2005. This distinction lost its relevance with the approval of a new law of private investment (Law 14/2011).

35 For a more complete understanding of this question, see also the sections regarding state land, abandoned and mechanisms of identification of land rights (see sections 7.1, 7.2, and 9).
} 
succession of states (Ederington, 1997: 266). ${ }^{36}$ The doctrine of acquired rights establishes that the alteration of sovereignty over a territory does not change acquired rights. This does not mean, however, that those rights are beyond the jurisdiction of the new sovereign state: rather, the "new sovereign can adjust property rights through general, non-discriminatory legislation" (Ederington, 1997: 311). However, this doctrine of acquired rights has been criticised in cases such as countries experiencing decolonization, considering the unfair patterns of land ownership set during the colonial administration (Fitzpatrick, 2002: 143).

In the case of Timor-Leste, it is necessary to distinguish between Portuguese and Indonesian land titles when considering the application of the doctrine of acquired rights. As pointed out by Fitzpatrick, the application of the international law of belligerent occupation would consider all titles granted after the Indonesian occupation invalid (Fitzpatrick, 2002: 58). However, as Fitzpatrick points out, not recognizing Indonesian land titles would be extremely unfair to those Timorese who acquired land rights in good faith during the Indonesian occupation. Furthermore, the application of the international law of belligerent occupation can conflict with international norms regarding housing security and protection against unreasonable eviction, ${ }^{37}$ these international norms are automatically incorporated into the Timorese legal system by the Constitution and are therefore directly applicable (article 9.2 of the Constitution).

The Timorese Constitution is silent about the validity of land rights granted prior to independence. ${ }^{38}$ It is arguable that Law 1/2003 decided not to recognize rights given by the Indonesian administration, but there are doubts regarding the range and validity of its provisions (see sections 7.1 and 9.1). In favour of the recognition of previous rights, it can be argued that the incorporation of Indonesian and UNTAET legislation in the Timorese legal system — with no exceptions made regarding land rights_-validated all land rights recognised therein, including rights granted or converted during the Indonesian administration of Timor-Leste. ${ }^{39}$ This seems to be the position adopted by Timorese courts, which recognize land rights obtained during Portuguese and Indonesian administrations without questioning if those land rights were received by the Timorese legal system. ${ }^{40}$ As the courts, the government has also been accepting these rights, albeit inconsistently and without clear legal basis; however the destruction of the Indonesian land registry and overlapping land claims complicates the acceptance of these rights. Nonetheless, the interpretation that land rights given during previous

\footnotetext{
36 International law will be mentioned only briefly, considering that this paper focuses on national legislation.

${ }^{37}$ Article 11 of the Covenant on Economic, Social and Cultural Rights (considering also the General Comments 4 and 7) and article 25.1 of the Universal Declaration of Human Rights.

38 This statement should not be confused with the criminalization of illegal appropriation of immovable assets that occurred before the entry into force of the Constitution (article 161 of the Constitution). This unclear criminalization was later regulated in articles 5 and 6 of Law 1/2003.

39 The fact that Indonesian law converted Portuguese land titles into Indonesian land titles should also be taken into consideration (see below in this section). Fitzpatrick et al. mention an equivalent recognition of land rights during UNTAET's administration (Fitzpatrick et al., 2012: 99). It is important to point out that a generalized recognition of previous land rights does not validate the cases in which those land rights were acquired through unlawful methods, such as corruption, coercion, or forgery.

40 For example, decisions of the Court of Appeal No. 07/2009 of 02/02/2010; No. 23/01 of 10/03/2010; No. 06/2003 of $16 / 07 / 2009$. One exception is a decision of 16/07/2008 of the Court of Appeal (without number, regarding Hotel Resende), in which the Court makes use of Law $1 / 2003$ to explicitly affirm the validity of the aforamento rights issued during the Portuguese administration and affirm that the disposal of state property during the Indonesian Administration is not valid.
} 
administrations are still valid is not accepted by all Timorese: in land-related public debates, it is common to hear calls for a 'clean slate' approach.

The question becomes more complex in the case of ownership rights of foreign citizens. Article 54.4 of the Constitution establishes that only national citizens can own land. ${ }^{41}$ However, the applicability of this article is not clear: Does it mean that, after the approval of the Constitution, foreigners are no longer entitled to acquire property in Timor-Leste, or does it apply also to land rights acquired during previous administrations? If the latter is true, will the state pay any compensation for the loss of these assets? ${ }^{42}$ What happens if an individual has lost Timorese nationality regains it in the future? And what if an asset is claimed by a Timorese national that is an heir of a foreigner? The Constitution gives no clear answer to these questions.

It is possible to argue that ownership rights of foreigners were terminated by the simple application of the Indonesian law incorporated in the Timorese legal system. Article 21.1 of the Indonesian Law No. 5/1960 (BAL, or Basic Agrarian Law, Undang-Undang PokokPokok Agraria) limits ownership rights (hak milik) to Indonesian nationals and establishes in article 21.3 that the holders of ownership rights who no longer fulfil the nationality requisite have one year to relinquish or transfer those rights to an eligible party. Based on a historical and teleological interpretation in the context of the Timorese legal system, these provisions restrict those rights to only Timorese nationals and give all nonTimorese a period of one year to relinquish or transfer their ownership rights. Considering that the sale of land rights by non-resident Indonesian nationals and Indonesian corporations was forbidden by article 1 of the UNTAET Regulation No. $2000 / 27$ - and later by article 13.3 of Law $1 / 2003$, which forbade any kind of transference by foreigners -, these assets could only be relinquished, not transferred. Consequently, it is arguable that all the ownership rights held by foreigners after independence were terminated through the application of the BAL.

But there are different positions regarding the rights of foreigners. Pedro Xavier de Sousa, former National Director of DNTPSC, claims that article 54.4 does not intend to nationalize foreigners' land ownership, and this provision will be clarified in forthcoming legislation (Sousa, 2005: 4; see also Leigh, 2006: 11). Sousa also proposes other solutions to the legal problem of foreigners' ownership rights: offer them land rights other than ownership or allow a period in which they can sell their property or acquire Timorese nationality (Sousa, 2005: 6). In the decisions of the Court of Appeal analysed it is not possible to find a consistent position regarding the ownership rights of foreigners. Some rulings of the court mention the pre-condition of Timorese nationality for the recognition of ownership rights, without considering when those rights were acquired. ${ }^{43}$ However, at least one ruling clearly states that foreigners cannot be deprived of their property before the approval of specific legislation regarding the rights of

\footnotetext{
41 The concepts of 'foreigner' and 'national' are at times misinterpreted. See section 6.2.

${ }^{42}$ A common answer of government officials to this question is that, during negotiations with Indonesia, Timor-Leste sustained the position that the country didn't want to be indemnified by Indonesia for all the destruction caused in 1999, but would not pay any compensation for the loss of property belonging to Indonesian nationals. However, it was not possible to clarify the forum of these negotiations and whether this position was ever formalized and agreed.

${ }^{43}$ Decisions No. 23/01 of 10/03/2010, No. 12/2009 of 10/03/2010 and No 07/2009 of 02/02/2010.
} 
foreigners. ${ }^{44}$ In conclusion, it is not possible to find in law, legal doctrine, and courts case law a conclusive answer regarding the validity of ownership rights held by foreigners before the entry into force of the Constitution.

There are also doubts regarding the validity of Portuguese and Indonesian land rights other than ownership rights held by foreigners. Article 54.4 of the Constitution is often invoked by state officials to justify the invalidation of any previous land rights given to foreigners by previous administrations. However, the restriction established in the Constitution is limited to ownership rights, not other land-related rights (see section 6.2). Nevertheless, if the BAL is applied, the land rights other than ownership held by foreigners also lose their validity. Articles 30.1 (a) and 36.1 (a) of the BAL restrict hak guna usaha and hak guna bangunan rights to Indonesian nationals, and article 42 limits hak pakai rights to Indonesian nationals and foreigners (individuals or corporate bodies established under Indonesian law) domiciled in Indonesia. ${ }^{45}$ For hak guna usaha and hak guna bangunan rights, the law establishes that the holders of these rights who no longer fulfil the nationality requisite have one year to relinquish or transfer those rights to an eligible party (article 30.2 and 36.2). Applying the same historical and teleological interpretation mentioned above, combined with the prohibition of selling land rights, those rights could only be relinquished. The same restrictions can also apply to the land rights issued during the Portuguese administration to non-Timorese nationals. The Indonesian government Regulation No. 18/1991 established a mechanism that converted all Portuguese land rights into the 'equivalent' Indonesian land rights. ${ }^{46}$ Therefore, the same principle of restricting foreigners' Portuguese land rights other than ownership rights based on the provisions of the BAL and Regulation 18/1991 could also be applied. It has been common practice of the government to not recognize any land rights issued to foreigners by previous administrations; there are even cases of foreigners leasing from the government land to which they held land rights issued by the Indonesian government. Regarding court decisions, the author found no ruling discussion this subject.

In conclusion, while international law tends to protect land rights acquired prior to independence, the Timorese law is unclear regarding this matter. And while there is a clear (but not unquestioned) acceptance by government officials and the courts of previous rights held by national citizens, the validity of rights held by foreigners is even more uncertain. It can also be argued that any land rights given by the Indonesian authorities were excluded by Law 1/2003, but the provisions of Law 1/2003 used the justify this position raise doubts regarding the range and validity of such provisions (see section 7.1 and 9.1).

\footnotetext{
${ }^{44}$ Decision No. 31/2003 of 13/05/2009

${ }^{45}$ All of these land rights give temporary access to land for a specific period of time. Regarding the characteristics of these three rights, see section 6.4 .

${ }^{46} \mathrm{It}$ is not clear if the Portuguese land rights were automatically converted by this regulation, but the text of the law seems to indicate that the conversion was automatic. Nevertheless, the process of converting Portuguese into Indonesian land rights had limited participation. Fitzpatrick reports that, in 1998, only 142 Portuguese titles were successfully converted and integrated into the Indonesian land system of land administration (Fitzpatrick, 2002: 159). The fact that Article 5 of this regulation was suspended by Government Regulation 34/1992 should also be noted. The effects of this conversion of Portuguese aforamento rights is further debated below.
} 


\section{2- Ownership Rights}

The Constitution establishes some founding principles regarding ownership of property in Timor-Leste. Article 54.1 establishes that "every individual has the right to own private property and can transfer it during his or her lifetime or on death, in accordance with the law." 47 It is possible to identify at least four components of the right to private property: (1) freedom to acquire assets; (2) freedom to use and enjoy the owned assets; (3) freedom to transfer the property of owned assets; and (4) a right to not be arbitrarily deposed of those assets (Canotilho \& Moreira, 2007: 802). ${ }^{48}$ The ownership right allows, under the limitations of the law, the exclusive and total use, enjoyment and possibility to dispose of the asset. The legal doctrine establishes that besides the use, the right of enjoyment that comes with property rights allows its beneficiary to collect the fructus naturales (e.g., the fruits of a tree) and civiles (e.g., the rent of a leased property) of an asset (Lima \& Varela, 1997: 94).

The right to private property established in article 54.1 is not an unrestricted right: the Constitution also establishes some limitations to it. Article 54.2 determines that private property cannot be used to the detriment of its social purpose. ${ }^{49}$ The real meaning of this provision is often debated. One influence for this article could have been article 6 of the Indonesian BAL, which refers to the social function of the land (see also article 33.3 of the Indonesian Constitution). ${ }^{50}$ The first outcome of this provision is that the individual interests of the owner of property should be adjusted to the interests of other people and the state (Explanatory Memorandum of this law, section II [4]). Authors have raised concerns regarding this interpretation, considering that Indonesian authorities often used the concept of land's social purpose to justify arbitrary dispossession by the state (Plessis \& Leckie, 2000: 7; Fitzpatrick, 2002: 131; Reerink, 2011; Devereux, 2015: 252). ${ }^{51}$ In the case of the Timorese Constitution, the interpretation that the 'social function of the land' allows land dispossession is incorrect, considering that land acquisition for public purpose is specifically regulated in article 54.3. A second consequence of article 6 of the BAL is that individuals should take care of the land and protect it from damage (Explanatory Memorandum of this law, section II [4]). This second consequence of the Indonesian BAL seems more relevant for article 54.2 of the Constitution, which can be interpreted as a declaration that ownership rights do not give unlimited powers to their holders and can be restricted based on the social function of property. For instance, the owner of a parcel of land cannot freely build on the land without obtaining building and environmental permits, which impose restrictions on the use of land for the general

\footnotetext{
47 It is not uncommon to hear this article being interpreted as meaning the government has to give a parcel of land to each person. The author has been in public meetings in which even the specific minimum area of this hypothetical parcel was debated. The origin of this idea could be found in the Indonesian Law 56/1960 (UU56/1960), which established the government's obligation to make available a minimum of 2 hectares of arable land for each farmer household (Lucas \& Warren, 2013: 3).

48 This reference refers to the analysis of article 62.1 of the Portuguese Constitution, with very similar text.

49 The same expression is later used in article 15.2 (c) of Law 1/2003.

50 The main reason for comparing this article of the Timorese Constitution with the Indonesian law is the common reference made by state officials to the 'social purpose' of the land to justify dispossession by the state, in line with the Indonesian interpretation. But other constitutions also refer to the 'social purpose' of the land. See for instance article 5.XXIII of the Brazilian Constitution, and article 110.2 of the Mozambican Constitution.

51 Referring to African examples, Cotula alerts us to an equivalent situation: the use of a requisite such as 'productive use' of land gives an arbitrary power to land officials (Cotula, 2012: 59).
} 
benefit of society (an equivalent idea of social function of the land is described by Fernandes, 2009: 203).

Another restriction to the right to private property is established in article 54.3. The power to expropriate entitles the state to obtain temporary possession (requisitioning) or to acquire the property of an asset (expropriation) against its owner's will. ${ }^{52}$ This power is restricted by the following cumulative criteria: (1) the public purpose of the expropriation or requisitioning; (2) payment of fair compensation; and (3) respect for the legal procedure established by law. ${ }^{53}$ Article 54.3 only establishes basic principles; therefore, to make this article implementable, subsequent legislation is needed (Vasconcelos, 2011: 203). However, until now, no legislation regarding expropriation has been approved. In theory, it would be possible to make use of the Indonesian expropriation law that was in force in 1999, instead of approving new legislation, but in practice the Indonesian legislation is simply not used. ${ }^{54}$ It should be pointed out that without further regulation, the open concepts of 'public purpose' and 'fair compensation' can represent a risk of arbitrary dispossession for private interests, ${ }^{55}$ as the Timorese people well know. ${ }^{56}$

The Constitution also establishes restrictions regarding who can own land in TimorLeste. Article 54.4 establishes that "only national citizens have the right to ownership of land". The colonial past and the history of occupation in Timor-Leste make the significance of this provision quite understandable. ${ }^{57}$ But the wording of this article raises doubts regarding its interpretation and no clarification can be found in subsequent legislation. ${ }^{58}$ Here, the discussion of the ownership rights of foreigners before independence should also be taken into consideration (see section 6.1).

The difficulties interpreting article 54.4 of the Constitution start with the expression 'national citizens'. In the terminology used by the Constitution, 'national citizen' is used

\footnotetext{
52 In legal English, the power to expropriate is also called 'eminent domain' (Mello, 2002: 310). The right of the states to expropriate property upon fair compensation is acknowledged by the Resolutions No.3281 (Charter of Economic Rights and Duties of states) and No. 1803 (Permanent Sovereignty Over Natural Resources) of the General Assembly of the United Nations. The requisitioning is only possible in exceptional, urgent and abnormal cases, and under strict time limits (referring to a similar provision in the Portuguese Constitution, Canotilho \& Moreira, 2007: 806).

${ }^{53}$ Canotilho and Moreira refer to a principle of legality of the expropriation: the expropriation procedure needs to have a legal basis that regulates it (Canotilho \& Moreira, 2007: 807). Further, it is not possible to expropriate without an administrative act that declares the public purpose of the expropriation.

${ }^{54}$ The article 18 of the BAL establishes the principles of expropriation, but defers the regulation of the process to specific legislation. The process was regulated by Law 20/1961.

55 Especially in countries where the justice systems are fragile and the legal doctrines not very developed, the concept of 'public purpose' can be an easy channel for dispossession, usually linked with the idea of "economic development" (Cotula, 2013: chapter 4, paragraph 19). It is questionable whether the mention of "ownership and useful possession of land as one of the factors for economic production (...)" in article 141 of the Constitution consents to a broad definition of public purpose, allowing, for instance, the expropriation of unused land. Nevertheless, any expropriation would have to respect the criteria of public purpose, fair compensation, and respect of the legal procedure established in article 54.3 (Vasconcelos, 2011: 445).

${ }^{56}$ As described by Fitzpatrick, during the Indonesian occupation, the Timorese experienced several kinds of unlawful dispossession, often with no public benefit and with no or limited payment of compensation (Fitzpatrick, 2002: 116). Understandably, the topic of expropriation raises strong concerns and fears among the population.

57 It is common to find concerns regarding the sale of land to foreigners in the media. But the same concerns are not new and were evident even during the Portuguese administration (e.g., Administrative Rule [Portaria] No.193 of 27 of July 1914, published in the Official Journal in $1^{\text {st }}$ of August 1914). On this topic see also Figueiredo, 2011: 5.

58 The restrictions to foreign rights over land is not exclusive to Timor-Leste or developing countries. For more on this topic, see Cotula, 2012: 72. Devereux gives some detailed information about the debate of this article by the Constitutional Assembly (Devereux, 2015: 250).
} 
to refer only to individuals (natural people) that have Timorese nationality. ${ }^{59}$ The expression 'national citizens' does not comprise legal entities such as corporations, associations or foundations (Urresta, 2004: 5). Therefore, can legal entities own land in Timor-Leste? ${ }^{60}$ And if they can, is there any limitation regarding membership of these legal entities? ${ }^{61}$ These questions are important for companies, foundations, and associations, but also for the Catholic Church, a key-player in the Timorese land sector; if the Constitution does not allow the recognition of land rights to legal entities, the Catholic Church is excluded from owning land in Timor-Leste. ${ }^{62}$ Further, a literal-albeit extreme - interpretation of this provision would also exclude the Timorese state from owning land in Timor-Leste, since by definition the state is also not a 'national citizen'.

The interpretation of article 54.4 of the Constitution is also complicated by a common misinterpretation in Timorese society regarding national citizenship. In Indonesia, dual nationality is forbidden by law (article 17 of Indonesian Law 62/1958 and currently article 23 of Indonesian Law 12/2006). After independence, a number of Timorese opted for keeping their Indonesian passports and living in Indonesia. A common opinion is that these people are not Timorese: because they are now Indonesian citizens, they are not Timorese anymore. However, because Timorese law does not forbid double nationality (Jerónimo, 2011: 12), it is only necessary to fulfil the requisites established in the Constitution to be an original Timorese citizen (Article 3 of the Constitution). ${ }^{63}$ Further, the renunciation of Timorese nationality is only possible after one has completed the specific procedure established by the national legislation. ${ }^{64}$ Therefore, the interpretation that the Timorese people that kept their Indonesian nationality are not Timorese nationals anymore, is incorrect.

Another common concern raised in public debates about land is the fact that foreigners can acquire Timorese nationality through marriage or long-term residency in the country, ${ }^{65}$ and consequently can own land. Regarding the right to own land, the Constitution does not establish any distinction between original and acquired citizenship. ${ }^{66}$ Consequently, and based on the principles of universality, equality, and

\footnotetext{
59 The exact expression 'national citizens' in only used in article 54.4 and 146.1 (regarding members of the national defence force). Citizenship is delimited in article 3, and further regulated by Law 9/2002 and Decree-Law 1/2004.

60 Urresta and Nixon point out in their findings that, based on their interviews with members of parliament and senior government officials, there is a strong support for the solution that allows Timorese legal entities to own land, if those legal entities are controlled by Timorese nationals (Urresta \& Nixon, 2004b: 15).

61 More difficult questions can be asked when we look deeper into this problem: What would be the solution in the case of foundations, which do not have members and 'live' independently of their founders? What about associations in which the membership is rather fluid (e.g., football club)? Despite not directly addressing these questions, subsequent legislation admits the possibility of public corporations own immovable property (e.g., article 16 [r] of Decree-Law 3/2003 that creates the APORTIL; article 14.1 [c] of Decree-Law 20/2008 that creates the National Petroleum Authority). Also article 2 of Law 1/2003 mentions the possibility of legal entities owning property, but does not clarify whether all legal entities have this right.

62 While it is not possible to get up-to-date data, it is reported by many people that the Catholic Church is one of the main land owners in Timor-Leste.

63 This interpretation is also followed by the Court of Appeal. See for instance the decision of the Court of Appeal No. $23 / 01$ of $10 / 03 / 2010$.

${ }^{64}$ Articles 14.1 of Law 9/2002 and 16 and 17 of Decree-Law 1/2004.

${ }^{65}$ Articles 11 and 12 of Law 9/2002 and article 9, 12, 13 and 14 of Decree-Law 1/2004.

66 The Constitution distinguishes the rights of original and naturalized citizens only once. According to article 75.1 (a), only original citizens can be presidential candidates.
} 
also the rules for the restriction of fundamental rights ${ }^{67}$ naturalized citizens can also own property in Timor-Leste (Jerónimo, 2012: 16). ${ }^{68}$

A second issue of article 54.4 of the Constitution is raised by the expression 'right of ownership'. The Constitution only restricts land ownership for foreigners. But in the Timorese legal system there are other rights in rem that, due to their nature, are almost equivalent to ownership rights. ${ }^{69}$ While this does not represent legal difficulties, those almost-equivalent rights can in practice conflict with the strong protective feelings about selling land to foreigners.

A third difficulty of article 54.4 of the Constitution comes with the word 'land' (terra, in the original Portuguese version). The word terra can mean land, but also soil or dirt. Acknowledging that it is not plausible that the constitutional legislator wants to prevent foreigners from owning soil or dirt, we can conclude that the intention was to refer to the land. As outlined above, Timorese law considers the ground as immovable property, and everything permanently attached to it as integral parts of that land. But this definition of immovable property does not match with the traditional idea that constructions and trees can be owned separately from the ground in which they are incorporated. ${ }^{70}$ While this concept of separation of ownership of the ground and constructions, trees and buildings can be legally established through the allocation of surface rights, the idea of 'ownership of the land' separated from the 'ownership of buildings and plantations,' causes misunderstandings and legal uncertainty. ${ }^{71}$

\footnotetext{
${ }^{67}$ Article 24 of the Constitution.

68 The Court of Appeal, in its decision No. 07/2009 of 02/02/2010, recognized the ownership rights of a foreigner over an immovable property, based on the fact that he was married with a Timorese woman, and according to their matrimonial property regime the asset was communal property of the couple.

${ }^{69}$ Article 1414 of the Civil Code allows the creation of surface rights - the right to build or plant on others' land (see more details in section 6.4). This right can be perpetual and gratuitous. Besides the obligation to build or plant within 10 years of getting the surface right (article 1426.1 [a]), and not having the right to enjoy the subsoil (article 1423), surface rights can be moulded to a right in rem very similar to ownership rights (the ownership right of the owner does not disappear, but is severely restricted by the surface right).

70 See section 5.1. It is interesting to note that article 161 of the Constitution regarding illegal appropriation of assets refers to 'immovable property' in general, not making any distinction.

71 In a debate regarding land-related legislation in which the author participated, Timorese members of parliament were sure that while foreigners cannot own land in Timor-Leste, they are allowed to own apartments, because in this case they don't own the land. This interpretation of the law is doubtful: the fractioning of one immovable property (e.g., offices building) in sub-parts (e.g., apartments) is done through article 1334 and following of the Civil Code, which establishes the legal regime of 'horizontal property' (propriedade horizontal). According to this regime, the owners of these sub-parts (e.g., apartments) are co-owners of the land and structural parts of the building (article 1341.1 [a]). If the owner of an apartment is the co-owner of the land, foreigners cannot own apartments because they will also be owners of the land. About the debate of this topic in the Constitutional Assembly see Devereux, 2015: 253.
} 


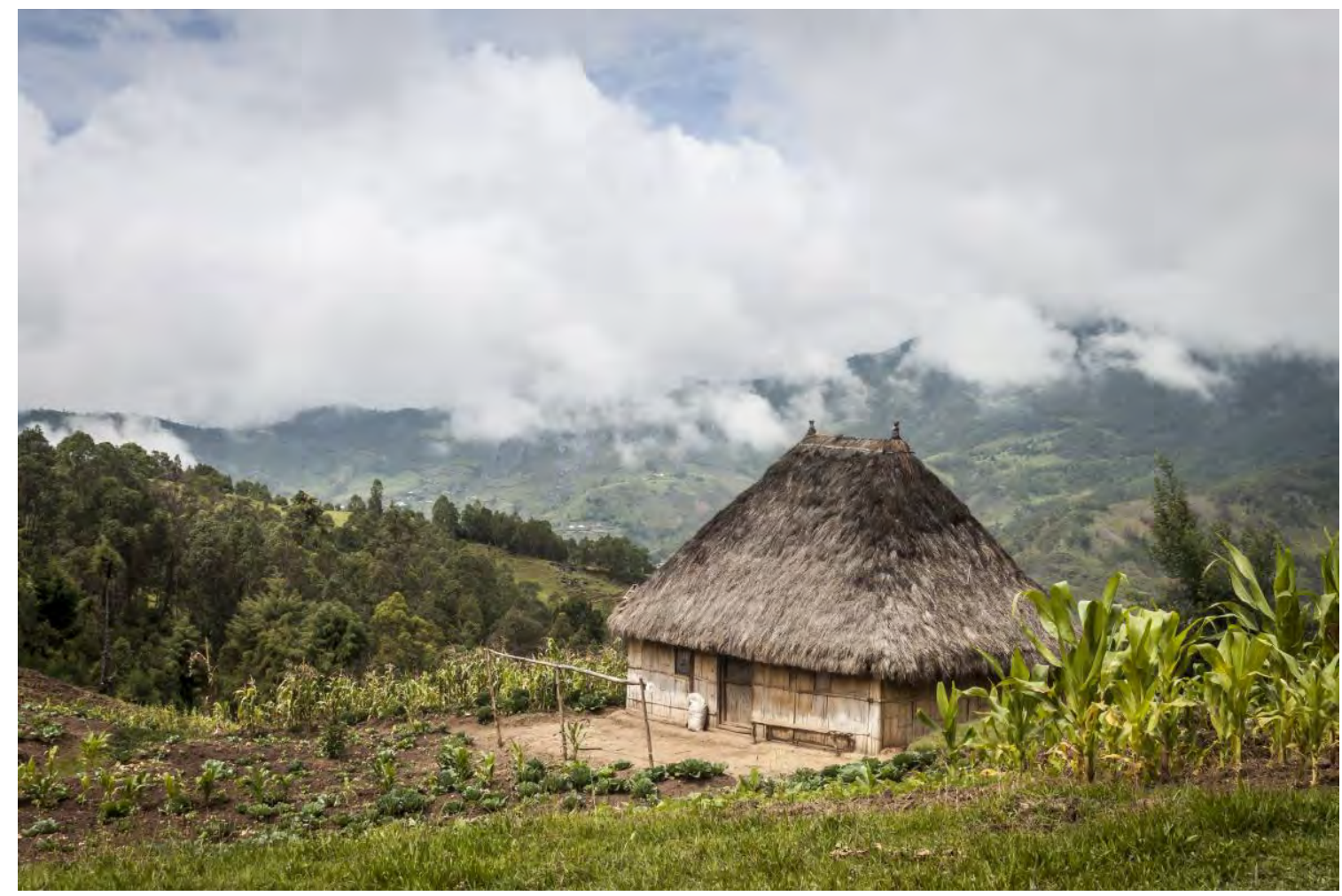

In conclusion, it is necessary to clarify the details of the nationality restriction for owning land. While clarification of article 54.4 of the Constitution by a subsequent law could bring legal clarity, a revision of the text of the Constitution would be more prudent. An 'interpretation' of this unclear provision through any legislative process other than a constitutional revision risks being declared unconstitutional in the future.

Timorese Constitution does not establish any gender discrimination regarding ownership rights. The customary prohibition of women owning land in patrilineal areas of the country is commonly discussed in land-related public debates. ${ }^{72}$ The Constitution is clear in this case, establishing a principle of equality (article 16) and even reinforcing this principle with article 17 that especially targets gender equality. Therefore, there is no legal restriction on women owning land in Timor-Leste. ${ }^{73}$

\section{3- Portuguese Resolvable Ownership}

During the Portuguese administration, a number of public servants acquired houses from the state-owned Fund for Economic Housing, through the legal regime of resolvable ownership. ${ }^{74}$ Under this legal regime, the price of a house sold by this Fund was paid in monthly instalments, and the buyer was bound by some restrictions (e.g., the buyer could not lose the status of public servant or agent, could not host non-family

\footnotetext{
72 According to Narciso et al. only 12.5 percent of the Timorese population belong to matrilineal customary groups, and not all of these people follow matrilineal traditions (Narciso et al., 2012: 5).

${ }^{73}$ While the Court of Appeal did not explicitly refer to the Constitution to affirm the right of women to own land, in a number of the decisions analysed, the Court recognized women's property rights (see, for instance, decision No. 12/2009 of 10/03/2010 and decision No. 06/2003 of 16/07/2009).

74 Portuguese Legislation: Decree-Law 23052; Decree 46602; Administrative Rule (Portaria) No. 3848; article 2171 Civil Code of 1867 and the article 1307 Civil Code of 1966. To the author's knowledge, most of these houses were located in Dili.
} 
members without authorization, and could not undertake works on the house without authorization). The lack of payment of instalments or the breach of the imposed restrictions allowed the termination of the contract by the Fund.

In recent years, the Court of Appeal has ruled at least one case of resolvable ownership (decision of the Court of Appeal No. 57/2003 of 04/06/2010; see also Penha, 2012: 108). In this case, the Court ruled that the buyer (or buyer's heir) had to prove the payment of the final instalment in order to claim the ownership of the house..$^{75}$ This interpretation causes huge problems for some owners of houses bought under the resoluble ownership legal regime. The law that regulated this regime established that unless it was explicitly established differently in the contract, the ownership of the house would be transmitted to the buyer with the signature of the contract. This ownership right would be burdened with the mentioned restrictions and the obligation of paying the instalments; and the Fund could resolve the sale and get back the ownership of the house in case of breach of these restrictions or lack of payment, but otherwise the house belonged to the buyer (Vieira, 2008). Therefore, a buyer (or a buyer's heirs) ought to prove only that he or she acquired the ownership right; it is the state or other interest party that have the burden of proving that the ownership right was resolved. ${ }^{76}$ Contrary to the position of the Court of Appeal, the payment of the last instalment is not a fact that allows the transmission of the ownership to the buyer; the payment of the last instalment only terminates the possibility of the Fund to resolve the contract. ${ }^{77}$ Until the effective resolution of the contract, the buyer still owns the house. The resolvable ownership cannot be mistaken with 'title retention'. This interpretation is especially relevant because in many cases the payment of the monthly instalments was halted due the end of the Portuguese administration and currently there is no record of these payments. In conclusion, in cases of resoluble ownership, the owner of the land is not responsible for proving the payment of the last instalment; the state is the one that must prove the effective resolution of the contract.

\section{4- Land Rights Other Than Ownership}

Ownership rights are not the only land rights recognized in Timor-Leste. As mentioned above, the Timorese legal system has incorporated major parts of the Indonesian legal system that was in force before 25 October 1999, and notably the BAL. ${ }^{78}$ This piece of legislation not only regulates ownership rights (hak milik), but also other land-related rights such as long-lease rights with a maximum of 25 years for individuals and 35 years for companies (hak guna usaha); construction rights with a maximum term of 30 years

\footnotetext{
75 The Dili District Court also decided at least one case of resoluble property: decision of 11/10/2009 in the case No. 42/Cível/2009/TD.DIL.

${ }^{76}$ Regarding this matter see also the following judgements of the Portuguese courts: judgement No. 358/06.8TBSRE.C2 of the Tribunal da Relação de Coimbra; decision No. JTRL00021960 of the Tribunal da Relação de Lisboa; decision No. JSTJ00041092 and No. JSTJ00007135 of the Supremo Tribunal de Justiça. A different position can be found at the judgement JTRL00001437 (Tribunal da Relação de Lisboa). These court decisions can be found at http://www.dgsi.pt/. 77 According to article 511.3 of the Civil Procedure Code, approved by Decree-Law 1/2006, in the case of a resolutory condition, the defendant is responsible for proving that the fact under that condition effectively happened.

${ }^{78}$ As said by Reerink, "the BAL is a product of its time (...) full of aspirations and symbolic meaning as a number of its key provisions are vague and ambivalent" (Reerink, 2011: 60).
} 
(hak guna bangunan); and usage rights (hak pakal) (Reerink, 2011: 61). ${ }^{79}$ The current status of the BAL in the Timorese legal system is unclear, as debated below.

The Timorese Civil Code regulates ownership rights, but also establishes a myriad of other rights in rem. These can be divided into rights of enjoyment (e.g., ownership rights), real security rights (e.g., mortgages), and rights that give to their holder privileges in the acquisition of specific assets (e.g., preferential rights with real effects) (Fernandes, 2009: 153). Considering the limited scope of this paper, the author will only briefly mention the main characteristics of the rights of enjoyment (besides the already analysed ownership rights): usufruct rights, use and habitation rights, surface rights, and easements.

The usufruct right allows the enjoyment of the asset (article 1362). However, this enjoyment is restricted in time - to the life of the beneficiary or 30 years if the beneficiary is a legal entity (article 1366) - and cannot change the substance of the asset. The right of use and habitation allows the use of an asset, but limits this use to the necessities of the beneficiary (article 1407). The surface right allows its beneficiary to build or plant on another's land (article 1414). This right can be temporary or perpetual and onerous or gratuitous (articles 1414 and 1420). ${ }^{80}$ Easements are defined in the Civil Code as the burden that a property imposes on other property with a different owner (article 1433). ${ }^{81}$

The current status of land rights under the BAL and the rights in rem established in the Civil Code is unclear. Article 3 of Law 10/2011 establishes that, "Regarding rights over immovable property, the new Civil Code is only applicable after the recognition or attribution of the first titles of the Democratic Republic of Timor-Leste." Furthermore this law does not repeal the BAL or regulate any transition between the two legal regimes. Therefore, new questions arise: Is the BAL still applicable? What is considered a 'first title'? Is the registration of rights by the registry created by Decree-Law 27/2011 considered a 'title' for the sake of this article? It is arguable that, until the attribution of those 'first titles', the Indonesian BAL remains applicable and this part of the Civil Code is not yet applicable. The court decisions analysed for this paper do not give any answer to these questions.

Another question is whether the Portuguese aforamento rights held by Timorese are still valid. The aforamento allowed the transfer of the right of enjoyment of a parcel of land from the state (senhorio) to a private person or legal entity (foreiro), for a specific purpose, upon the payment of an annual amount (foro). The aforamento was perpetual, ${ }^{82}$ and, unless this possibility was restricted in the contract, the foreiro was allowed to acquire the property right after 40 years of aforamento, upon the payment of 20 foros. ${ }^{83}$

\footnotetext{
${ }^{79}$ Regarding the validity of Indonesian land rights held by foreigners, see section 6.1.

${ }^{80} \mathrm{~A}$ surface right can be shaped into something very similar to a property right. See section 6.2.

81 The classic example is a property without access to a public road. A legal easement can be imposed on a neighbouring property to allow this access (article 1440). The definition of easement in the Civil Code highlights the close relation of the rights in rem with their object - the rights in rem cannot exist without the asset that they refer to (Fernandes, 2009: 63).

${ }^{82}$ Article 1492 of the Portuguese Civil Code of 1966, combined with article 104 of the Legislative Diploma (Diploma Legislativo) No. 865. The legal base mentioned is the last approved by the Portuguese administration; other legislation is applicable to older aforamentos.

83 Articles 1511 and 1512 of the Portuguese Civil Code of 1966, combined with article 105 of Legislative Diploma No. 865. The possibility of acquiring the ownership of the land could be limited in the concession agreement.
} 
The above-mentioned Indonesian Government Regulation No. 18/1991 converted the aforamento rights of individuals into hak guna bangunan rights for 25 years or hak guna usaha rights for 20 years, depending on their nature (articles 3.1 [a] and 3.1 [b]). The aforamento rights of religious and social entities were converted into hak pakai rights, for the period of time that, and on the condition that, the land was being used for their religious or social activities (article 3.2 [c]). The aforamento rights held by Timorese were technically converted into the above-mentioned Indonesian temporary land rights. Those Indonesian land rights have already expired or will soon expire, considering that 25 years have passed since 1991. The fairness of this regulation is contested by the holders of aforamento rights, who consider their rights significantly reduced, especially regarding the imposition of a timeframe or a specific use in the case of the religious or civil entities. An additional argument advanced by holders of aforamento rights is that in 1976, after the Indonesian occupation, the Portuguese legislator converted all the aforamento rights into ownership rights. ${ }^{84}$ In the court cases analysed for this paper, two cases were identified in which the Court considered an aforamento right terminated based on the application of the Indonesian Government Regulation No. 18/1991.85 No cases were found in which an aforamento right was recognized as such. By contrast, while there is no common practice established, the aforamento rights tend to be recognized by the public administration.

\section{5- Lease Contracts of State and Abandoned Land}

Lease contracts can also guarantee access to land, and should therefore be included in a broader definition of land rights. In the case of Timor-Leste, the analysis of lease contracts is especially relevant, because since the administration of UNTAET lease contracts of state land and abandoned land under the administration of the state have been the most secure way to access land. ${ }^{86}$

The first Timorese legislation regarding leases was approved in 2004. Decree-Law $19 / 2004$ regulates the allotment of state and abandoned land. When the beneficiary is a public entity, the process is called 'allocation'; when the beneficiary is an individual or a private legal entity, the allotment is done through a lease (article 4). ${ }^{87}$

The allocation of property for the use of public entities is done through a simple process in which the use of state assets is requested to the Ministry of Justice (article 5). The

\footnotetext{
${ }^{84}$ Portuguese Decree-Law 195-A/76, later amended by Law 108/97, and also article 101.2 of the Portuguese Constitution of 1976. This decreelaw refers to enfiteuse rights, which is another name for aforamento rights. It is, however, debated whether this transformation into property rights would include the aforamento rights that were given in the Portuguese Colonies. See for instance the decision No. JTRL00001026 of the Portuguese Tribunal da Relação de Lisboa (available at http://www.dgsi.pt//.

85 The Dili District Court, in its decision of 25/10/2011 in the process No. 58/Civel/2011/TD.DIL applied this interpretation of the law. This decision was later confirmed by the Court of Appeal (process No. 05/Cível/Apelação/2012/TR of 01/06/2012). The Court of Appeal followed the same interpretation of the law in the case No. 08/Cível/2013/TR of 29/05/2013.

${ }^{86}$ UNTAET intervention regarding land governance was almost limited to allocation of lease contracts over state land and abandoned property (at the time designated as temporary use agreements). However, those leases faced a difficult challenge: if public buildings were relatively easy to identify as state land, without a land registry or any legal process to identify existing land rights, there was no mechanism to verify if the occupants of property were the lawful owners of the land, thereby making it very difficult to identify abandoned property (Thomson, 2003: 24)

87 In 2011 the approval of lease regulations in the Civil Code did not repeal this decreelaw. Article 17.2 of Law 10/2011 that approves the Civil Code specifically repeals Law 12/2005 regarding the leases between privates but does not repeal
} 
lease of state land to private entities is restricted to property in the private domain of the state (article 2). ${ }^{88}$ This decree-law also establishes that abandoned property is managed by the state and can be leased or allocated, but under a special legal regime (chapter IV of Decree-Law 19/2004).

The lease of state land is regulated in chapter III of Decree-Law 19/2004. Nationals and foreigners, individuals and legal entities can request to DNTPSC to lease a specific property (article 9) for housing, ${ }^{89}$ offices, commerce, industry and agriculture (article 10). But, besides the priority order for different purposes of leases established in article 10.1, there are no criteria for cases in which the lease of property is requested by more than one person. This has led to several kinds of disputes (e.g., the lease contract for land first requested by one party being awarded to another party; a tenant who made improvements to a property wanting to renew the contract, but the land is awarded to another party). The lease of property for medium- and large-scale commerce or industry should be preceded by a public tender process to access other possible interested parties in the property. ${ }^{90}$

All leases have to be made in writing (article 13). The time-limit for the lease of state property depends on the purpose of the lease, and can have a maximum of 50 years (article 14), ${ }^{91}$ but the time-limit can be longer in special cases (article 14.3). Article 11 provides the criteria for establishing rent prices, but the specific value of the rent

\footnotetext{
Decree-Law 19/2004. Nevertheless, the rules of lease contracts established in the Civil Code can be used to address gaps in the special regime of leases established by Decree-Law 19/2004.

${ }_{88}$ Regarding the public and private domain of the state, see section 5.2. While article 2 mentions the possibility of approving specific regulation regarding the private use of property in the public domain of the state, that legislation was never approved. It is not explicitly said, but article 27 of Decree-Law 19/2004 seems to include the shoreline areas in the definition of public domain.

89 After the approval of Law 1/2003, a 'special lease program' was created. This program targeted the regularization of the occupancy of state land and abandoned land under administration of the state that was left behind by the Indonesian legal entities and individuals and later occupied for residential purposes by national citizens. This program allowed simplified lease contracts for the period of one year (automatically renewed) and with a monthly rent of USD $\$ 10$, for occupants of property since 2000 (Sousa, 2005: 7; Leigh, 2006: 10). According to DNTPSC officials, the program was later implemented in other districts with a rent of USD\$5, and a total of 3,030 contracts were signed $(2,903$ in the district of Dili). However, this process was never formalized in any kind of legislation. As stated by DNTPSC officials, a public statement of the former Minister of Justice was interpreted by the beneficiaries as a suspension of the program: no more of these contracts were awarded and no more rents under these leases were paid.

90 The distinction between small-, medium- and large-scale commerce or industry was established in Ministerial-Decree $1 / 2006$. This distinction was based on the value of the rent to be paid by the tenant. There is, however, a problem: the value of the rent should be calculated based on an official rent value table, but this table was never approved. Ministerial Order No. 019 /GM/MJ/II/2009 of the Minister of Justice established a new criteria for this distinction, based on the amount of investment. However, these new criteria raised new doubts: considering that the regulation of this matter should be a general regulation and not an administrative decision, the regulations that are part of the ministerial order should have been approved as a ministerial-decree. With the approval of Law 14/2011 regarding investment the distinction of small-, medium-, and large scale was abandoned for holders of an investment certificate (article 24). The procedures for the public tenders were further regulated in Ministerial-Decree 1/2006. Despite all the existing regulations, the procedure of public tenders has been systematically ignored. To date, the author knows of only one case in which this procedure was followed.

91 Article 24 of Law 14/2011 regarding private investment established new limits for the holders of an investor's certificate: "The state may enter into a lease agreement concerning property belonging to the state with the holder of an Investor's Certificate for a maximum time period of fifty years, renewable once for an equal period of time." But this article raises doubts regarding its interpretation: does this renewal need the agreement of both parties or is it an option of the tenant? In the author's view, this article should be interpreted as follows: the contract can have a maximum of 50year period. If, at the end of the initial period, both parties want to renew the contract, they can do so for the same period as the initial period, and are exempted from following the legal formalities that preceded the signature of the agreement, such as a public tender for the contract awarding. After the end of the renewal period of the lease contract, any subsequent lease of the property should be subject to all legal formalities. If the renewal was an option of the tenant only the maximum limit of the lease would be, in practice, of 100 years.
} 
depends on a ministerial-decree that has not yet been approved. ${ }^{92}$ Decree-Law 19/2004 also establishes the obligations of the state and the leaseholders (articles 7 and 8), limitations regarding the possibility of transfer the position of leaseholder or sublease of the property (articles 15 and 17), and the criteria for termination of the contract (article 16). According to article 18 no compensation will be paid for any kind of improvements the tenant may make to the property.

Abandoned properties are under state management and can also be leased (article 15 of Law 1/2003 and article 20 and following of Decree-Law 19/2004). ${ }^{93}$ The lease of abandoned property has some restrictions in order to balance the demand for using abandoned property with the possibility of the return of its lawful owner. Abandoned property can be leased for a maximum of three years (renewable) and, in the case of the owner returning, the contract remains valid and the owner takes the position of the state in the contract (article 22.2 and 23 of Decree-Law 19/2004).

\section{6- Lease Contracts Between Private Parties}

The lease contracts between private parties are now regulated by the Civil Code (article 953 to 1040). ${ }^{94}$ Such leases were previously regulated by Law 12/2005, but this law was expressly repealed by the approval of the Civil Code (article 17.2 of Law 10/2011). Article 8 of Law 10/2011 regulates the transition from Law 12/2005 to the Civil Code. An indepth analysis of the legal regime of lease contracts between private parties falls outside of the scope of this paper, but the main characteristics of lease contracts between privates are that they are limited to 50 years (article 957) and should be made in writing (article 1016). Contrary to what was established by Law 12/2005, the lease contracts do not have to be registered. ${ }^{95}$

\section{7- Legal Protection of the Holder of a Lease Contract}

Given the number of overlapping land claims, it is important to analyse the tenure security of tenants: what legal protection can the holder of a lease contract have? ${ }^{96}$ Article 988.1 of the Civil Code establishes that the acquirer of an asset will take the position of the previous owner in the lease contract, which remains in force. Therefore, if a leased immovable property is acquired by a third party, the tenant is protected, but the acquirer of the asset can be surprised with the unexpected burden of having a tenant, especially considering that the lease contracts are not registered. The acquisition

\footnotetext{
92 In Dili, a rent valuation scheme that was created under the Land Law Project II is used, but has never been formalized (ARD, 2006). The lack of formalization creates problems regarding the transparency of rent values.

93 Regarding the problems identifying abandoned property, see section 7.2 .

${ }^{94}$ Regarding lease contracts between privates, one should also consider the restriction to the lease of land by non-resident Indonesian citizens or Indonesian companies that was established by article 2 of UNTAET Regulation 2000/27.

${ }_{95}$ Article 5 of Law 12/2005 established that the lease contracts should be registered at DNTPSC. This provision proved not to be effective: firstly, there were no procedures established for this registry; secondly, no legal effects for the registry of lease contracts were established; thirdly, the tenant had the main interest in having the lease registered, so he or she could secure the rights given to him or her by the lease, but by law the person obliged to register the lease was the landlord. Some leases were registered, but the 'registration' was not more than giving a copy of the lease contract to DNTPSC.

96 This question is closely related with the doctrinal debate of the nature of lease rights: are these rights in rem or rights in personam? The Civil Code does not give a clear answer regarding this debate. Fernandes discusses the same question based on similar provisions of the Portuguese Civil Code (Fernandes, 2009: 171).
} 
of the land can be voided if the acquirer proves that he or she did not know about the lease contract (articles 242 of the Civil Code).

A different situation occurs when a third party can successfully prove that the landlord is not the lawful owner of the property. In this case, the lease contract cannot be used against the lawful owner (article 964 of the Civil Code. See also Lima \& Varela, 1997: 364). Nevertheless, there are some legal mechanisms that can be used by the tenant against the lawful owner in such a case: possible acquisition of the land through the acessão mechanism (article 1260 of the Civil Code) ${ }_{1}^{97}$ compensation from the owner of the land for unjust enrichment in case of improvements made on the land by the tenant (article 408 of the Civil Code). The tenant can also seek compensation from the person that leased the property (article 964, 962 and 963 of the Civil Code).

It is possible to conclude that, although the lease contracts have been used as a recurrent mechanism to get access to land in Timor-Leste, the tenure security obtained with these contracts is limited. In practice it depends essentially on the trustworthiness of the landlord.

\section{7- WHICH LAND IS STATE LAND?}

\section{1- How the Law Defines State Land?}

One of the main elements of Law $1 / 2003$ is the definition of state land. In the drafting of this law there was a strong concern in reaffirm the illegality of the Indonesian occupation (see the preamble); consequently, article 4.1 establishes that, "(a) All real estate assets owned by the Portuguese state as of 7 December 1975; [and] (b) real estate assets that are acquired by the state by virtue of law or juridical act" are considered part of the private domain of the state. The article does not mention the property acquired during the Indonesian administration. Yet, this article needs to be read together with article 16. According to article 16, "Real estate assets acquired or built by public entities within the period [of the Indonesian administration] shall be automatically forfeited to the state" (article 16.2), ${ }^{98}$ and any alienation of state property during this period should be considered invalid, except if the asset was acquired by a third party in good faith (articles 16.1 and 16.3). ${ }^{99}$ However, the provisions raise several legal problems.

Article 16.1 holds that any act of disposal of property made by the Indonesian administration during the period of the Indonesian occupation, made in whatever form,

\footnotetext{
${ }^{97}$ Acessão happens when the asset of one person is combined with the asset of another person. In the case of buildings or plantations on another's land, depending on the value of the assets (building/plantation and land), and the good faith of the builder or planter, the asset can be acquired by the builder or the planter, upon the payment of compensation to the lawful owner of the land.

98 The destiny of the property that was constructed or acquired during the Indonesian administration is quite relevant, considering the number of assets that were acquired during this period. For instance, of 762 state properties identified in Oe-Cusse Ambeno in 2002, 94 percent were acquired during the Indonesian occupation (Yoder, 2005: 312). However, the solution adopted by this law raises questions regarding its fairness, considering the number of properties that were acquired or simply confiscated through violence by the Indonesian administration and army, without payment of fair compensation. On dispossession by the Indonesian administration, see Fitzpatrick, 2002: 115.

99 It seems that article 16.3 mistakenly mentions article 16.2 instead of article 16.1 (see below).
} 
should be considered non-existent. This provision raises a question regarding its scope: does it comprise only property rights that were permanently transferred by the state to a private party (hak milik)? Or also temporary land rights in which the property of the asset is kept by the state (e.g., hak guna bangunan or hak guna usaha)? Urresta, involved in the draft of Law $1 / 2003$, says that this provision terminated all the land use rights issued during previous administrations (Urresta \& Nixon, 2004b: 27). ${ }^{100}$ Nevertheless, the legal doctrine is not uniform regarding what should be considered an 'act of disposal' in opposition to 'an act of administration', leaving doubts regarding the scope of this provision. ${ }^{101}$ In conclusion, it is not clear if this article is only applicable to Indonesian ownership (hak milik), or also to Indonesian land use rights (e.g., hak guna bangunan, hak guna usaha).

It can also be debated that article 16.1 violates the Constitution: as mentioned above, it is arguable that the Timorese Constitution, by incorporating the Indonesian legislation (including land legislation), validated the land rights acquired during previous administrations, at least the rights held by national citizens. If article 16.1 extinguishes already recognized previous land rights, it is carrying out a de facto expropriation, without any declaration of public purpose and payment of compensation, thereby violating article 54.3 of the Constitution. Furthermore, as mentioned above, there are cases in which the termination of these rights would violate international norms regarding housing security and protection against unreasonable eviction. Consequently, in the author's view, this provision is unconstitutional, even if considering the mitigation mechanism of article 13.3 (see below). Moreover, if the objective of this provision was to nullify all the transactions of state land during the Indonesian occupation, it should have been done in the Constitution and not through a law.

In practice article 16.1 is virtually ignored by the public administration. This article is also unmentioned by many authors (see Yoder, 2005; Penha, 2012; Fitzpatrick et al., 2012). As mentioned above, in all the court decisions analysed for this paper article 16.1 is mentioned a single time, and is not applied to nullify any land right.

Article 16.2 determines that all assets acquired or built by public entities during the period of the Indonesian occupation automatically become property of the state. This provision is problematic as well. While it makes sense that assets that were lawfully acquired by the Indonesian administration revert to the state, ${ }^{102}$ the automatic acquisition of all assets built or 'acquired' by the Indonesian administration raises the same constitutional doubts as in article 16.1: many of those constructions and assets were acquired through unlawful mechanisms; those acquisitions were null or

\footnotetext{
100 In its decision of 18.07.2008 (Appeal of the process 03/Cível/2002/TD.DIL), the Court of Appeal affirmed that article 16.1 did not cover the aforamento rights, issued by the Portuguese administration. In the decision 42/Cível/2009/TD.DIL of 10.11.2009 the Dili District Court also mentions this article, but does not use it for the decision. These were the only times that article 16.1 is mentioned in all the court decisions analyzed for this paper.

${ }^{101}$ As a comparative example, Article 955 of Civil Code establishes that a lease for longer than six years is not an act of administration, but an act of disposal.

102 This would be the principle established in article 16.1 (a) of the 1983 Vienna Convention on Succession of States in Respect of State Property, Archives and Debts. As analysed in detail by Fitzpatrick, the Indonesian rule of Timor-Leste could not be considered an annexation; therefore, there was no succession of the Indonesian state to the new Timorese state (Fitzpatrick, 2002: 52). But the principle itself presents a fair solution for the cases in which land was lawfully acquired by the Indonesian administration.
} 
sometimes even inexistent; therefore the asset belongs to its lawful owner. Ignoring this fact and simply consider all as state land, independently of the conditions in which such 'acquisitions' happened, is a de facto expropriation, because legally the asset never belonged to the Indonesian administration. Only in those cases where the asset still serves a public purpose (e.g., a school), the state should be able to claim it, but only after legally expropriating that asset and paying a fair compensation.

Article 16.3 intends to protect third parties who acquired state land in good faith for a fair price. According to this article, 'the rights of bona-fide third parties that have onerously acquired estate assets through a fair price shall be safeguarded (....)'. This provision could minimize the impacts of the previous articles, but also has significant limitations. Firstly, it seems that in article 16.3, article 16.2 is mistakenly mentioned instead of article 16.1. Article 16.3 refers to people who acquired property from the state in good faith, which relates to article 16.1, and not 16.2. Secondly, it is only applicable to third parties, not to people who in good-faith acquired land directly from the Indonesian administration. Thirdly, criteria such as 'good-faith' or 'fair price' can promote arbitrariness, especially when used in administrative procedures with such harsh effects and unclear processes as the ones established in Law 1/2003. In any of the court decisions analysed this provision was ever mentioned.

The definition of state land adopted by Law 1/2003 raises another important question: what is the legal status of customary land and its relation with the definition of state land? This subject will be covered below (see section 8).

\section{2- Does Abandoned Property Belongs to the State?}

Article 15 of Law 1/2003 gives the power to administrate abandoned property to the state, allowing for its lease to nationals, foreigners and legal entities. But it is debated what rights the state has over abandoned property or even whether abandoned property should be considered as under ownership of the state.

A first challenge comes with the concept of 'abandoned property.' A definition was only established in article 20 of Decree-Law 19/2004, which defined as abandoned, "all unoccupied, occupied, or illegally appropriated property pursuant to articles 5 and 6 of Law 1/2003 of 10 March (Juridical Regime of Immovable Goods) identified by the National Directorate of Land and Property as privately owned up until September 1999". The criteria established in this definition raise several questions: first, what is unoccupied land? ${ }^{103}$ If the land is being used by others than the lawful owners, do those users have to be convicted of the crime of illegal appropriation or occupation established in article 5 and 6 of Law 1/2003, prior to identification of the land as abandoned? ${ }^{104}$ What is the legal procedure to identify a land as being abandoned? In practice Land is administratively identified as 'abandoned' by DNTPSC based on a single visit to the site

\footnotetext{
${ }^{103}$ Regarding concerns about the use of the concept of 'abandoned land' or 'vacant land,' see Contula, 2013: chapter 2, paragraph 5. As pointed out by Contula, the fact that no one is on the land does not mean that it is abandoned (e.g., swidden cultivation; grazing land, sacred places).

104 Note that DNTPC was obliged to report all of these crimes to the Public Prosecutor (article 14 of Law 1/2003). In practice this communication is rarely done.
} 
and without any legal administrative act of declaration of a property as abandoned. This approach raises doubts regarding its legality; it lacks a clear legal basis, interested parties have no chance of contesting the results of the identification, and the identification process lacks any kind of publicity.

Second comes the question whether abandoned property is now state land. Article 12.3 and 12.4 of Law 1/2003 establish a presumption that unclaimed land belongs to the state. However, as debated below, some presumption raises serious doubts regarding its legality and its practical implementation. The same doubts are raised regarding the provision of article 13.2 that contradicts article 15.1 (see section 9.1). Therefore, the author's opinion is that Law $1 / 2003$ cannot be used by the state to claim abandoned land as state property. On the other hand, article 1265 of the Civil Code establishes that immovable property without a known owner is considered state property. ${ }^{105}$ While this is a common default provision in civil law countries, ${ }^{106}$ it should be interpreted carefully, especially in the Timorese context: property can only be considered 'without a known owner' and therefore as state property after an adequate process of identification, in which that property was not claimed by anyone. ${ }^{107}$ Currently, only Decree-Law 27/2011 provides a procedure for the identification of property rights over land through a systematic cadastral survey, and this procedure is only adequate to urban areas, not to the large extensions of customary land. ${ }^{108}$ Bearing in mind these limitations, land left unclaimed through the process established in Decree-Law 27/2011 can be registered as state land ( also article 1265 of the Civil Code). However,as for all registrations, ade through Decree-Law 27/2011, the registration of abandoned property as state land can always be challenged in court (article 4.2 of Decree-Law 27/2011; article 517 and 518.2 of Decree-Law 1/2006).

\section{3- Eviction from State Land}

Articles 7 to 11 of Law 1/2003 established an administrative procedure for evicting occupants of state property and the procedures for appealing against the eviction. ${ }^{109}$ After having identified an asset as state property, the DNTPSC notifies the occupant to vacate the property within 30 days (article 7.1). ${ }^{110}$ The occupier has 10 days after the notification to file an administrative petition to the Minister of Justice (article 7.2). This administrative petition is considered tacitly dismissed if there is no response from the Minister of Justice within 15 days (article 7.3). After the term of 30 days has elapsed,

\footnotetext{
${ }^{105}$ Articles 27 (a) 1, 34 (e) and 40 (e) of the BAL establish that hak milik, hak guna bangunan and hak guna usaha rights can be terminated if the land has been abandoned. In the explanation of article 27 (Explanatory Memorandum), it is established that, "Land is abandoned when it is deliberately not used in line with its condition or with the nature and purpose of the right on it." Besides the difficulties raised by this rather vague provision, its application cannot be separated from a previous process of identifying existing land rights and the characteristics of those land rights.

${ }^{106}$ Article 1345 of the Portuguese Civil Code; with more details regarding the act of abandonment, article 1276 of the Brazilian Civil Code; article 713 of the French Civil Code; article 17 of the Spanish Law 33/2003 regarding the state property.

${ }^{107}$ Note that Van Vollenhoven's interpretation of adat law in the Indonesia argued that there was no 'owner-less' land in Indonesia (Lucas \& Warren, 2013: 28).

108 Regarding the land claims process and its effects created by Decree-Law 27/2011, see section 9.2.

109 Article 7 does not explicitly refer to abandoned property. However, considering that the state has the power to administer abandoned property (article 15), it seems possible to more broadly interpret article 7 in order to include abandoned property. The administrative procedure in general is regulated by Decree-Law 32/2008.

110 The 30-day term does not comply with the 90 days prescribed in article 56 (j) of UN Basic Principles and Guidelines on Development-based Evictions and Displacement.
} 
the DNTPSC is entitled to vacate the property, if necessary by police force (article 8.1). ${ }^{11}$ Judicial appeal of the eviction order does not halt the eviction (article 8.2), but a preventive action can suspended the eviction until a final decision of the court (article 305 of the Civil Procedure Code, approved by Decree-Law 1/2006). ${ }^{112}$ The evicted person is responsible for paying the expenses of the eviction (article 8.3) and is not entitled to any compensation for improvements made to the property (article 8.4). The legal procedure for the appeal of the eviction is established in articles 10 and $11 .{ }^{113}$

The procedure for eviction established in Law 1/2003 is very harsh for the evicted people: First, the law provides no detail regarding the process of identifying a property as state property. In practice the state only declares that a property is state property in the notification for eviction, shifting the burden of proof to the occupier. ${ }^{114}$ The lack of a more formal procedure raises doubts regarding the legality of this practice. Second, especially considering the significant problems in accessing the formal justice system and the low levels of literacy and legal knowledge of the population, the opportunity for a meaningful appeal is, at least, very limited. Third, the fact that judicial appeal does not suspend the eviction puts on the evicted person's shoulders a second burden of having

to support the costs of not being able to access the disputed land until the final decision of the court is reached. While it is legally possible to directly invoke international norms regarding housing security and protection against unreasonable eviction (see section 6.1), in practice the public administration tend to ignore those norms. The author could not find any court decision in which the eviction procedure of Law 1/2003 was challenged due to incompliance with international norms.

In practice a financial compensation is often paid by the state to the people evicted from state land. However, this happens on an ad hoc basis without any legal framework, resulting in arbitrariness. ${ }^{115}$ Decree-Law 6/2011 attempts to establish the legal basis for the payment of 'humanitarian support' for people evicted from state land and some criteria for determining the compensation value. However, the implementation of this Decree-Law is dependent on the approval of regulations regarding the values of

\footnotetext{
111 Often DNTPSC negotiates with the occupants the vacancy of the property before issuing a notification, and extends the timeframe for more than 30 days. But formally the eviction can occur any time after the 30 days term.

112 No administrative court or specific legislation regarding administrative proceeding in court has yet been approved. While legally the Indonesian law could be used, in practice the courts have been applying the rules of the Procedural Civil Code (Guerreiro, 2012: 72).

113 It is arguable that these articles of the judicial procedure were repealed by the approval of the Civil Procedure Code (article 4 of Decree-Law 1/2006 that approves the Civil Procedure Code - not the Code itself, but the decreelaw that approves it). The decision 16/Cível/Agravo/2011/TR of 25/09/2013 determined that the special procedure of Law 1/2003 should be followed, but does not analyse what was later established in the above-mentioned article.

114 In Timor-Leste, this burden of proof is often quite 'heavy': registries were destroyed in 1999; many of the land rights based on custom were never formalized and have weak legal recognition; and the lack of legal structures and legal knowledge made most transactions informal and therefore formally invalid. This burden can, however, be shifted by the presumption or ownership in the Civil Code in case of possession (see section 10.3).

115 This arbitrariness can be illustrated with two well-known examples: (1) in 2011 the government evicted around 147 families from old Indonesian police barracks (also known as Brimob neighbourhood) where those families were living since 1999; each family received a compensation of 2000 USD (Matadalan ba Rai Haburas Foundation, 2010: 62-64). (2) In 2012 the government evicted 11 families from land considered by DNTPSC as state land, in the Aitarak Laran neighbourhood, for the construction of the new building of the Ministry of Finance; the families received between 2500 and 6500 USD, depending on the size and condition of their houses and plantations of some of those families (see for instance Business Timor 28/12/2012).
} 
compensation. Those regulations were yet not approved and therefore this decree-law has never been used.

The above-mentioned Decree-Law 4/2014 regarding the administrative predeconcentration establishes in article 6.2 (c) that the "structures of administrative predeconcentration", regarding state land that they administer, have the power to order the eviction of illegal occupants. It is not yet clear if the eviction procedure established in Law $1 / 2003$ is going to be used in the evictions promoted by the structures of administrative pre-deconcentration, or that a special regulation will be made.

\section{8- DOES THE STATE RECOGNIZE CUSTOMARY LAND RIGHTS?}

A great majority of the Timorese base their land rights in customary land tenure systems, and most of the country's territory is claimed by local communities on the basis of customary law (Fitzpatrick, 2002: 167; Nixon, 2009: 3). ${ }^{116}$ Therefore, it is crucial to analyse how the Timorese legal system deals with customary land rights.

The legal recognition of customary land rights is incipient. The Constitution recognizes existing customary practices, as long as they are not contrary to the Constitution, and any law regulating customary law (article 2.4), but makes no reference to customary land rights. In practice this means that the Constitution gives no protection to customary tenure, leaving that possibility to the legislature. The Indonesian legislation incorporated in the Timorese legal system by means of the Constitution offers a degree of recognition of customary rights to land; however, the recognition to customary tenure given by the $B A L$, offers little protection when the state wants to appropriate it. Furthermore, the recognition given by the BAL to customary tenure is not applicable to forest land, which in Indonesia represents most of the country's area (Fitzpatrick, 2002: 86, 126). ${ }^{117}$

Law 1/2003, the first Timorese land-related law, ignored customary land rights. ${ }^{118} \mathrm{~A}$ small change came with the approval of Law 10/2011. Article 4 establishes that the land that is used communally by a community according to its usages and customary practices, is that community's property. However, besides this article there is no other reference to community property, leaving the regime of the community property quite unclear. Furthermore, the concept of community property differs from the concept of

\footnotetext{
116 The statistics of the 2010 Census also support the prevalence of customary land tenure: 91.8 percent of the respondents (79.9 in urban areas and 96.0 rural areas) claimed that they individually own the house where they live. When compared with the small number of land titles that have ever been given in Timor-Leste, it is safe to assume that most of these claims have a customary basis.

117 Forest land, regulated by the Basic Forestry Law (5/1967) and later replaced by Law 41/1999, refused the recognition of customary rights over forestry land, which represents 70 percent of the land mass of Indonesia (Lucas \& Warren, 2013: 8; Bedner, 2016: 46). Nevertheless, in 2013 the Decision No. 35/PUU-X/2012 of the Indonesian Constitutional Court recognized customary rights in forestry areas (Bedner, 2016: 52, 53).

118 The recognition of the traditional authority of customary elders in a draft law of 2005 was received with strong opposition by the political elite, which perceived the customary systems as feudal, discriminatory and contrary to modernization (Fitzpatrick et al., 2012: 102).
} 
customary land, despite the fact that in practice the two concepts at times overlap. ${ }^{119}$ Nevertheless, the provision of Law 10/2011 represents a change in the existing policy towards the recognition of customary rights to land.

A central question for the definition of customary land right is their relation with the definition of state land established in article 4.1 of Law 1/2003. This article considers as state land all the properties previously owned by the Portuguese state. The law Portugal applied to its colonies, while recognizing some land rights to indigenous people, limited the recognition of their customary land rights to cultivated fields and housing areas. ${ }^{120}$ As in many other colonial states, the law did not recognize customary land rights over land used by communities for uses other than housing and cultivation, but central for their livelihoods, identity and culture (e.g., grazing, forestry, sacred areas). ${ }^{121}$ Consequently, the definition of state land established in Law 1/2003, while not explicit, has the potential to include vast areas presently held under customary law that are included in colonial definition of 'vacant' land, therefore allowing a new dispossession of the rural Timorese (Yoder, 2005: 312). There are cases of land acquisitions by the state in which customary claims to land were considered; however, there also other cases where the lack of any legal recognition of customary land rights allowed the state to ignore them.

In conclusion, while the Timorese legal system has some references to customary rights to land, it offers very limited security of tenure for communities and people that claim these rights. Most notably, the definition of state land established by Law 1/2003 represents a real threat to the claimants of customary land rights.

\section{9- HOW CAN LAND RIGHTS BE IDENTIFIED?}

\section{1- The Process Established by Law 1/2003}

The history of land tenure in Timor-Leste brings enormous challenges to the process of identification and recognition of land rights. A first attempt of collecting and recording land claims was made by UNTAET during its administration, but without a legal basis for this process (Yoder, 2005: 313).

Law $1 / 2003$, formalized a land claims process for the first time. Article 12 stipulated that within one year after the law entered into in force, national citizens should submit their claims to property rights to DNTPSC, together with documentary evidence to sustain

\footnotetext{
119 Land customarily claimed by a community, is not necessarily used in a communal way; customary land systems allow also more individual 'land use rights'. Furthermore, there are some individual land claims with customary basis. More generically about this topic, Dekker, 2005: 148.

120 The regulation of land rights in the Portuguese colonies started with the Carta de Lei of 1901 (an equivalent to a Law), but this regulation was modified and complemented by several other pieces of legislation. The analysis of the Portuguese legislation is outside of the scope of this paper; therefore, the statement above is fairly generic and does not represent all the intricacies of Portuguese legislation.

121 Regarding the same experience in Indonesia, even after colonial rule, see Lucas \& Warren, 2013: 28. More generically about colonial experiences, see Cotula, 2013: chapter 2, paragraph 5.
} 
them (articles 12.1 and 12.2). ${ }^{122}$ Unclaimed land would be presumed to be state land, but this presumption could be trumped in court if a case was filed before 31 December 2008 (articles 12.3 and 12.4). Moreover, the loss of land rights through this mechanism would not preclude the possibility of obtaining compensation for the loss of a right through a later court decision (article 12.5).

The application of this article raises several problems. First, article 12.1 only mentions ownership rights, excluding all other formalized land rights from the land-claiming process. ${ }^{123}$ Further, this article does not mention all ownership rights but only the ones in which the assets "have been illegally appropriated or occupied by third parties". ${ }^{24}$ As debated below, this hampers the application of the presumption established in article 12.3 that says that all unclaimed land is presumed to be state land, the presumption only makes sense if all disputed and undisputed land rights had to be claimed. Second, participation in this process was limited for other reasons. Out of the around 45,000 land titles issued during the previous administrations, only 12,329 claims were lodged, including around 9,000 claims of foreigners. ${ }^{125}$ This lack of participation was also related with the fact that this process was centred on formalized rights, not acknowledging customary land rights, and therefore excluding most of the population. Furthermore, only 33 percent of urban families and 15 percent of rural families knew about this obligation of claiming their disputed land rights (Urresta \& Nixon, 2004b: 29). In many cases it was moreover extremely difficult to provide documentary evidence that could prove the property rights, due to the massive destruction of registries and personal property. Third, the outcome of this land claim process depended on "mechanisms for mediation or administrative restitution of the respective title". These mechanisms were expected to be created in subsequent legislation that was, however, never approved, leaving the claims made under Law 1/2003 in a 'legal limbo'. ${ }^{126}$ Fourth, the legal presumption created in articles 12.3 and 12.4 raises several doubts as to its application. Article 12.3 establishes that 'unclaimed private immovable property without identified owners shall be presumed to be property of the state'. In discussions with DNTPSC staff about this article the author heard a number of times the first part of this article being interpreted as all the land that was not claimed through the land claim process of Law 1/2003 belongs to the state. But as discussed above, this land claim process was only applicable to cases of ownership rights that were illegally appropriated or occupied - not all immovable property - and, therefore, this interpretation seems incorrect (see also Urresta \& Nixon, 2004b: 28). Another common misinterpretation of article 12.3 is that abandoned land belongs to the state. This interpretation is far from what is effectively written in the text of the law, which does not talk about abandoned

\footnotetext{
122 The law entered into force on 10 March 2003. The official website (http://jornal.gov.t/) erroneously mentions 24 December 2003 as the publication date.

${ }_{123}$ See section 2. Despite this legal distinction, some holders of land rights other than ownership also claimed land through this process. This is representative of the existing misconceptions, both in the population and state officials, regarding the legal characteristics of land rights. For instance, it is common to see court cases in which the holder of a title of aforamento claims the recognition of his/her ownership right.

${ }^{124}$ Another question could be asked: what if the occupation happened after the law entered into force?

${ }_{125}$ According to Sousa, of those claims, 72 percent were lodged by foreign individual claimants, 26 percent by national individual claimants, and 2 percent by corporations (Sousa, 2005: 5).

${ }^{126} \mathrm{~A}$ first draft was prepared in 2005, under a USAID technical assistance program, but rejected by the Minister of Justice. A new draft was prepared but it was never debated due to the beginning of the political crisis of 2006 (Fitzpatrick et al. 2012: 102).
} 
land, but 'land without identified owners'. The article establishes two cumulative requisites: the land needs to be unclaimed, and it is not possible to identify the owner. This raises several questions: article 12.3 refers to unclaimed land, but claimed in what process? It cannot be the process established in article 12.1, because as analysed above, the land claim process of article 12.1 was restricted to 'disputed ownership rights' and did not include all existing land rights. Another question regards the meaning of 'without identified owners.' If the land was not claimed in a claiming process, but its owner is known by the community (e.g., absent owner), is this article applicable? Questions are also raised regarding article 12.4: what would be the legal solution if the property was 'abandoned' after 31 of December of 2008? Would the property immediately revert to the state?

All the above-mentioned questions regarding the presumption created by articles 12.3 and 12.4 raise serious doubts as to how it should be implemented. ${ }^{127}$ Albeit for different reasons, in 2004 Urresta raised similar concerns about the presumption of articles 12.3 and 12.4 and recommended an extension of the term for presenting land claims (Urresta \& Nixon, 2004b: 29). Presently, considering the absence of any legal solution for the claims presented under Law $1 / 2003$, the application of the legal presumption in favour of the state is even less defensible. None of the court decisions analysed for this study applied the presumption of article 12 .

Article 13 established a land-claim process for foreigners, similar to the one in article 12. Article 13.1 created an obligation for foreigners to, within the same timeframe as in article 12, claim the land that they owned by 19 May 2002, 'for the purposes that would be established in future laws'. Article 13.2 also created an obligation to present all the evidence documents together with the declaration, otherwise the claimed property would be considered abandoned and would revert to the state. Article 13.3 considered non-existent any transaction of immovable property made by foreigners after 19 May 2002.

This article raises questions regarding the fate of land rights of foreigners. Firstly, as in article 12, the claims process was limited to ownership rights, ignoring other land rights. Secondly, while article 13.1 uses the past tense to refer to the immovable property that belonged to foreigners, article 13.2 states that all the claimed property without the respective documentary evidence will be considered abandoned and will revert to the state. Then, article 15.1 establishes that abandoned property that belongs to foreigners is temporarily administrated by the state. Based on these articles, there are many questions without clear answers: Have foreigners lost their ownership rights in TimorLeste due to the approval of this law? ${ }^{128}$ What happens to an unclaimed property of a foreigner: does it revert to the state (article 13.2) or is it temporarily administered by the state (article 15.1)? What should be considered respective documentary evidence (article 13.2)? And how can it be justified that claimed immovable property without the

${ }^{127}$ The understanding of the land claims process and this presumption is even more unclear when reading Sousa, at the time National Director of DNTPSC: 'In essence, the claims process was to set a deadline for claims by non-residents, in order that the government could then address such issues, and not have new (and perhaps conflicting) claims arriving over time.' (Sousa, 2005: 5).

${ }^{128}$ See a possible solution mentioned in section 6.1 
respective documentary evidence reverts to the state (article 13.2), but abandoned immovable property is only administered by the state (article 15)? In the analysis of court decisions, the author found a single decision in which these articles are mentioned, and in that case they were not relevant for the final decision. ${ }^{129}$

The land claims process created by Law 1/2003 also raises a practical problem: for claiming their property, the claimants filled out forms where they identified the administrative location of the land, but no geo-reference point was associated with each claim. It is possible to conduct searches with the name of a claimant or search for all the claims in a certain hamlet (aldeia); but due to the lack of clear administrative boundaries, as well as incomplete claims, is not possible to assure that a certain property was not claimed with a different hamlet name or no reference to the hamlet. Therefore, in practice no search can be made to certify that a certain property is not claimed or is claimed more than once.

In conclusion, the land-claims process established by Law 1/2003 had limitations and did not solve the complex land tenure situation left behind by the Indonesian administration.

\section{2- The Process Established by Decree-Law 27/2011}

In 2011 the government approved Decree-Law 27/2011,130 with the objective of overcoming some limitations of Law 1/2003 and to start the registration of undisputed land parcels, identified through a systematic cadastral survey. This decree-law started a new process of land claims that left behind the claims of Law 1/2003. Prompting this decree-law was the work that at the time was being developed by the Ita Nia Raiproject (INR, or 'Our Land' in Tetun). ${ }^{131}$ Since 2008 INR had been conducting a systematic cadastral survey, progressively collecting land claims in the urban areas of the district capitals of the country. At the time more than 35,000 land claims had already been collected, and 92 percent of the parcels covered by those claims were not disputed..$^{132}$ However, this cadastral survey was being done without any legal basis to support it. ${ }^{133}$ At the same time, the draft law of the Special Regime for the Determination of Ownership of Immovable Property (known as the 'Land Law') had been waiting to be discussed in parliament for more than one year, and there was no prospect of it being

\footnotetext{
129 Decision of the Court of Appeal No 02/PC/2010/TR of 19/03/2010.

130 The author was directly involved in the drafting of this decree-law.

${ }^{131}$ Land tenure issues were identified as one of the fundamental causes of the political crisis of 2006 (Brady \& Timberman, 2006: 20). The INR was created by USAID to support the government in addressing those issues. The INR, together with DNTPSC, created a systematic process of land claims that started as a pilot program in 2008 in the urban areas of Liquiçá and Manatuto. After a downsizing of the staff in 2011, the project was definitively handed over to the Ministry of Justice by USAID in the middle of 2012. The handover process was criticized due to the inexistence of a realistic exit strategy, especially considering the low capacity of the Timorese institutions to receive this project. In 2013 the government decided to grant a sole-source contract for the continuation of the cadastral survey to a Timorese/Portuguese joint venture. This new project is now known as the Serviço Nacional de Cadastro, or SNC (Government Resolution 25/2013 and Government Resolution 28/2013).

132 The 92 percent refers to the number of undisputed parcels. There were cases in which one parcel was claimed by several claimants; therefore, the number of disputes cannot be calculated by a simple comparison of the number of parcels surveyed and the number of claims.

${ }^{133}$ There was a Ministerial Order of the Minister of Justice (Ministerial Order No. 229/GM/MJNII/2008) allowing the start of the cadastral procedure and establishing some criteria for its process. However, this ministerial order, by its own nature only has administrative value, and cannot not compel the population to participate in the procedure.
} 
debated anytime soon. The two main objectives of Decree-Law 27/2011 were to create a legal framework that could legitimize the work that was being developed by INR, and to strengthen the legal protection of undisputed claimants.

The legal framework for the cadastral procedure was established in article 5 of DecreeLaw 27/2011 and further developed by Ministerial-Decree 16/2011 of the Minister of Justice. The cadastral procedure is based on the systematic approach that was developed by INR: it is conducted in pre-determined cadastral areas, where geographical information and land claims are collected for all the parcels in each area (article 1 of Ministerial-Decree 16/2011). The process starts with a preliminary phase of public awareness-raising that involves community meetings, information meetings with local authorities, announcements of the process in the Official Journal (Jornal da República), and the broadcasting of public information campaigns in the media (articles 2.1 and 2.2). The second phase of the process is the in-the-field collection of geographical information and land claims of each parcel of the collection zone (article 3). ${ }^{134}$ Land claims are defined as the act through which each owner of a specific parcel claims ownership of that parcel through the cadastral procedure (article 2.1 [a] of Decree-Law 27/2011). The land claims can be presented by individuals, legal entities, communities, groups, and the state; and everyone is free to present their claims and the means of proof they consider relevant (article 4.1 and 4.2). ${ }^{135}$ After additional public information campaigns (article 2.3), the third phase of the process starts with the publication in the area of maps containing the delimitation of each identified parcel and its claimants for a period not shorter than 30 days (article 5.1, 5.2 and 5.3). During this period, any interested parties can correct their claims, present new claims, make counterclaims against claims already presented, and correct possible errors in the boundaries of claimed parcels (article 5.4). ${ }^{136}$ The parties in a court case regarding a property that will be part of the cadastral process should communicate the existence of the court case to the DNTPSC or risk having the disputed parcel registered under another claimant's name (article 11 of Decree-law 27/2011).

Ministerial-Decree 23/2011 of the Minister of Justice regulates the following steps of the procedure. When the period of publication of maps is over, two lists are published in the area: one list identifying the undisputed parcels that, according to the criteria established in law, will be registered as ownership of the beneficiaries; and a second list with all the other claims (article 2). The parcels claimed only during the publication period are not included in these lists and are separately publicized through a new process of publication of maps (article 3). ${ }^{137}$ All the parcels identified in the first list are registered as property rights in the National Property Cadastre database, and a registry certificate

\footnotetext{
134 Only information regarding the delimitation of each parcels is collected. Information regarding other elements such as constructions, plantations, and use of the land are not part of this procedure. While not established in this ministerialdecree, the procedure developed by INR recommends that neighbours should mark their boundaries prior to the data collection, and those marks should be recorded by the data collectors on a specific form, which is signed by both neighbours.

${ }^{135}$ No specific means of proof is required, thereby allowing those with land rights not previously formalised to claim land. The agreements made through mediation or negotiation between disputing claimants during the cadastral procedure are also accepted in the process (article 8.5 of Decree-Law 27/2011 and article 4.5 of Ministerial-Decree 16/2011).

${ }^{136}$ As referred to above, the cadastral procedure started in 2008 without the legal framework to support it. Article 13 of Decree-Law 27/2011 and article 6 of Ministerial-Decree 16/2011 intend to make usable the work developed before the approval of the law, without disadvantaging those that did not participate in a process that was not yet legally established. Therefore the period of publication of maps has to be reopened, so all the interested parties can present their land claims. 137 This provision attempts to avoid last-minute opportunistic claims over unclaimed land, without public scrutiny. Through this provision, all the claims are subject to at least 30 days of public display.
} 
is given to the claimants (article 4 and 6). In other words, the registration consists in a change of status in the existing database. The legal effects of this registration will be analysed below.

Decree-Law 27/2011 avoided all the controversial topics: can only register property rights over undisputed parcels, claimed by one or more individual persons identified as nationals, and undisputed parcels claimed by the state, leaving unregistered disputed parcels (articles 1.2 [a] and 1.2 [b] of Decree-law 27/2011 and 2.1 [a] of MinisterialDecree 23/2011). ${ }^{138}$ Furthermore, the registration of property rights in favour of legal entities or land claimed communally is deferred to a subsequent law, which has not yet been approved (article 1.2 [c] of Decree-law 27/2011 and article 2.1 [b] of MinisterialDecree 23/2011). However, under this Decree-Law, those entities must claim their land rights in order to register their claim over a certain parcel and to avoid the legal effects of unclaimed land.

If the claimants of a disputed parcel reach an agreement, the status of the parcel can be changed and registered according to their settlement (article 9.2 and 9.3 of Decree-law 27/2011 and article 8 of Ministerial-Decree 23/2011). The land claims presented by those without proof of Timorese nationality (i.e., national ID card, passport, or electoral card) are suspended until that proof is presented (articles 2.6 and 9 of Ministerial-Decree 23/2011).

This land claims process differs from the process that was established by Law 1/2003. ${ }^{139}$ Firstly, this process is not designed to be done nationally at one time, but progressively around the country. Secondly, the land claims are publicly scrutinised through the publication of the cadastral maps, which deters abusive or opportunistic land claims. ${ }^{140}$ Thirdly, the state, represented by the district DNTPSC officials, also has the burden to identify and claim its land. The proximity of the district state officials with the local population, and the stronger knowledge about the history of each parcel and of local perceptions of existing land rights, makes these officials less prone to claim as state land areas that are socially acknowledged to belong to individuals or communities. Fourthly, because it does not demand any specific documents, the process is more oriented to the social perception of property rights, rather than formalized status.

However, the land claims process of Decree-Law 27/2011 also has weaknesses. Firstly, as mentioned above, the land claims only refer to ownership rights. The process follows the existing perception in Timorese society that does not distinguish ownership rights from other land rights; but this can also be a source of uncertainty, with registered

\footnotetext{
138 If a claim raises doubts that the land belongs to the state, it can be excluded from the list of parcels to be registered (article 2.1 [b] of Ministerial-Decree 23/2011).

139 The next two paragraphs present advantages and shortcomings of this cadastral procedure. However, the advantages and disadvantages of the formalization of land rights in general and the specificities of this procedure deserve a much deeper analysis. On this topic, see for instance De Soto, 2000 and Otto, 2009. Specifically regarding the work of Ita Nia Rai, see Haburas Foundation, Rede Ba Rai, 2013.

140 INR staff recall stories in which claimants retrieved their land claims after feeling embarrassed for having excessive land claims publicly exposed in their community.
} 
ownership rights overlapping other unclaimed land use rights. ${ }^{141}$ Secondly, the registration of all undisputed claims as ownership rights without looking at the basis of the claims represents a double-edged sword: while it allows a better conformation to the local understanding of ownership rights (e.g., customary-based land rights of individuals; never formalized land rights) and accommodates the very diverse realities that exist in Timor-Leste (e.g., loss of documentation), it can also be a source of corruption and arbitrariness (e.g., land officials receiving bribes to not claim certain parcels as state land, or presenting selective state counterclaims). Thirdly, the procedures established for the cadastral survey were not designed for larger parcels in rural areas, usually claimed by communities on customary basis; despite accepting all kinds of claimants, including communities, the cadastral survey only registers claims of property, which does not take into consideration the complex network of different land rights that characterize customary claimed areas. This creates the risk of private appropriation of the land by the powerful members of a community, to the detriment of other community members. ${ }^{142}$ Some of these weaknesses are mitigated by the possibility of contesting the registration in court (see below), and the fact that unfair counterclaims by the state only result in disputed cases, but not in final decisions (the state has no legal advantage in those disputes). Nevertheless these limitations have to be acknowledged.

The second feature of Decree-Law 27/2011 is to strengthen the legal protection given to the undisputed surveyed parcels. As mentioned above, undisputed parcels claimed by one or more individual persons identified as nationals, or by the state, are registered as ownership rights at the end of the cadastral procedure. This registration gives the claimants a legal presumption of ownership over the registered parcel (article 4.2 of Decree-Law 27/2011). This legal presumption can be trumped in court. It is not a land title and does not give an ownership right over property to the exclusion of others, but presumes that the beneficiary is the owner of that property, unless the opposite is proven. ${ }^{143}$ This presumption gives strong advantages to its beneficiaries: firstly, they can act as legal owners of the land (transactions, mortgages, etc.); ${ }^{144}$ secondly, while the presumption can be challenged in court, the challenger has the burden of proving to have a right that trumps the registered right. Thirdly, the registration of parcels combined with deeded possession reduces the timeframe for adverse possession (article 1214 of the Civil Code). ${ }^{145}$ Decree-Law 27/2011 also establishes a legal safeguard for third parties; registered assets onerously acquired by third parties in good faith are not

\footnotetext{
${ }^{141}$ At the time of the drafting the idea was to adjust this Decree-Law to what was established in the 'Land Law' that was pending in parliament. In this law, aforamento, hak guna bangunan and hak guna usaha rights were all converted into property rights (with some restrictions). Customary rights were also recognized through this law.

${ }_{142}$ At the time of drafting the idea was to keep the cadastral survey to urban areas of district capitals, and slowly, according to the needs, expand it to other urban areas. Regarding the necessity and possible mechanisms for registering customary land rights see Delville, 2010.

143 Penha says that article 15 gives a constitutive effect to the registration made by Decree-Law 27/2011, preventing future claims in court regarding the lack of legal formalities in land transactions made prior to the registration (Penha, 2012: 22). This is not the author's interpretation: the revocation of Indonesian legislation made by article 15 needs to be read together with article 10.3 and 14 . These articles aimed for the creation of simplified formalities for the transaction of registered parcels, to be established by a ministerial-decree; there was no intention of giving a constitutive effect to the registration. However, this ministerial-decree regarding transactions has never been approved (see below).

${ }_{144}$ Mortgages are regulated in the Civil Code. However, the validity of mortgages is dependent on their registration (article 621 of the Civil Code), which, due to the lack of legal procedures for registering the mortgages, cannot be done. Therefore, it is currently not possible to validly mortgage immovable property.

${ }^{145}$ Regarding deeded possession, see section 10.2.
} 
affected by the nullification of the initial registration, if they register their acquisitions (article 10.8). However, this protection is only applicable three years after the registration of the acquisition (article 10.9). This protection is replicated by article 282 of the Civil Code. While this protection brings some security, the three years gap still represents a strong burden for the buyer. Furthermore, as mentioned below, the necessary legislation regarding the transactions of registered parcels was never approved, which is consequently causing a progressive outdating of the registry and not allows land owners to make use of all the benefits of their registrations.

With the end of the Ita Nia Rai project, the registration of surveyed parcels under DecreeLaw 27/2011 was slowly stopped, and the land registry was no longer publicly available. Currently cadastral surveys are being done by the Serviço Nacional de Cadastro (SNC), but no registration of undisputed claims has yet been made under this decree-law.

\section{0- LEGAL MECHANISM FOR ACQUISITION AND LOSS OF LAND RIGHTS}

\section{1- Acquisition of Land Rights through a Contract:}

Decree-Law 3/2004 that established the regime of the notaries was the first piece of Timorese legislation to establish that the recognition, creation, transfer, modification or extinction of rights in rem over immovable property, or other acts that could represent a burden over the property, should be done through a notary deed (article 37.2). ${ }^{146}$ This provision was later suspended by article 14.1 of Decree-Law 27/2011, which established that a provisional procedure for the acts mentioned above would be specified by a Ministerial-Decree (article 10.2). ${ }^{147}$ However, this ministerial-decree was never approved. With the entry into force of the Civil Code in March 2012, the obligation of a notary deed for transacting rights in rem over immovable property was again established (articles 808 and 809 regarding sale of the property right or other rights in rem; articles 874.1 and 881.1 regarding donations of rights). ${ }^{148}$ However, the lack of legal mechanisms for updating the registry made through Decree-Law 27/2011 does not allow buyers to secure their acquired land rights through registration. In conclusion, while currently the transfers of land rights have to be done through a notary deed, there is no legal mechanism to update the rights registered through Decree-Law 27/2011.

\footnotetext{
146 Decree-Law 3/2004 was later changed and regulated by Decree-Laws 24/2009 and 25/2009.

147 At the time, there was only one certified notary in the entire country. Therefore, the intention was to give the competency of formalizing those transactions to the District Directors of DNTPSC. Fitzpatrick et al. mention a case in Ainaro where, in the absence of notaries, the transactions were being documented in an informal system created by the local village head (Fitzpatrick et al., 2012: 235). Currently there are seven certified notaries in the country: one in the district of Oe-Cusse Ambeno, one in district of Covalima, one in district of Baucau, and two in the district of Dili. The other two are allocated to a special service for the creation of companies (SERVE).

148 The legislation necessary to regulate the transaction of state property has never been approved (article 4.1 of Law 1/2003 and article 28 of Decree-Law 19/2004).
} 


\section{2- Adverse Possession}

Adverse possession is a legal mechanism that allows the acquisition of a right in rem, through the reiterated possession of that right in rem for a certain period (Prata, 2005: 1241; Fernandes, 2009: 241).

Before the approval of the Civil Code, adverse possession was regulated by the Indonesian legislation that was incorporated in the Timorese legal system. Part of the existing doctrine states that Indonesian law does not allow adverse possession (Fitzpatrick, 2002: 83; Reerink \& Gleder, 2010: 80; Reerink, 2011: 90; Bedner, 2016: 43). ${ }^{149}$ Before the approval of the Indonesian BAL in 1960 the Indonesian Civil Code (from 1847) allowed adverse possession. However, Book two of the Indonesian Civil Code, containing some of the main provisions to justify adverse possession, was repealed by the approval of the BAL (point 4 of the list of repealed legislation. See also Bedner, 2016: 41); furthermore, the BAL -the Indonesian Land Law- does not make any reference to the possibility of acquiring rights through adverse possession. Nevertheless, the Timorese courts do apply the provisions regarding adverse possession established in the Indonesian Civil Code. ${ }^{150}$ These decisions never discuss whether adverse possession is admissible in Indonesia, and never refer the fact that book two of the Indonesian Civil Code was repealed by the Indonesian BAL.

The approval of the Timorese Civil Code introduced adverse possession in the Timorese land tenure system. ${ }^{151}$ To understand adverse possession in the Timorese Civil Code it is necessary to first distinguish possession from precarious possession (article 1173). In the case of precarious possession, the holder of the asset does not act as the beneficiary of the right in rem (e.g., someone holds an asset with the authorization of its owner). The precarious possessors are not possessors, and therefore the rules of adverse possession are not applicable to them. Second, the adverse possession is dependent on the characteristics of the possession and possible registration of that possession. There are four characteristics of possession: deeded or undeeded possession, depending on whether the possession was acquired through a legitimate acquisition process (article 1179.1); 152 bad-faith or good-faith possession, depending on whether the possessor knew or not that his or her possession was harming other people's rights (article 1180.1); violent or peaceful possession, depending on whether the possessor used violence to obtain his or her possession (article 1181); and finally, possession can be public or hidden, depending on whether the possession is exerted in a way that can be known by the interested parties or not (article 1182). Furthermore, according to the

\footnotetext{
${ }^{149}$ Adverse possession should not be mistaken with the provision of article 24 of the Indonesian Government Regulation No. 24/1997, which allows the registration of land rights without the necessary documents, if the person applying for registration has had possession of the land, publicly and in good faith, for more than 20 consecutive years.

150 See for instance the decisions of the Court of Appeal No 14/Cível/2013/TR of 30/07/2013, No 56/2003 of 30/03/2009, No 56/2004 of 01/06/2009. Also Penha, 2012: 80

151 Considering the doubts raised by the article 3 of Law 10/2011 regarding the application of the Civil Code to immovable property, it is questionable whether the provisions of the Civil Code regarding adverse possession are already applicable. In the decisions of the Court of Appeal analysed for this study such question was never considered. The rules of adverse possession established in the Timorese Civil Code are only applicable to possession that started or continued following the entry into force of this code.

152 This distinction is better explained with an example: A acquired land from B through a notary deed. Later, it was proved in court that B was not the legitimate owner of the land; therefore, the transaction was not valid. Because A was in possession of the land through the formal mechanism to acquire the property right (i.e. a notary deed), his possession is classified as 'deeded possession'.
} 
Civil Code the possession of immovable property can also be registered in the property registry, independently of the existence of any land right.

The acquisition of immovable property through adverse possession is regulated in articles 1213 to 1217 . Depending on the characteristics of possession and its registration, the right in rem can be acquired in 10 to 25 years of possession. ${ }^{153}$ Acquisition through adverse possession is not allowed if the possession is violent or hidden.

Considering the history of informal land tenure and dispossession in Timor-Leste, the adverse possession regulations could assume an important role in the process of land titling (Williams, 2009). But while adverse possession could represent a simpler mechanism for solving conflicting land claims, it is also important to consider the common understanding in Timorese society that long-term possession does not preclude others' ownership rights (Urresta \& Nixon, 2004b: 67; Fitzpatrick et al., 2012: 271).

\section{3- Legal Protections for Possessors}

The legal regime of possession is regulated in detail in the Civil Code (articles 1171 to 1206). Considering that most of the people who possess land in Timor-Leste do not have any formal land rights, the mechanisms established for protection of possession are especially relevant. Those mechanisms can be preventive measures in court in case of relevant fear of disturbance or disseizing of possession (article 1196); direct action and judicial defence of the possession (article 1197); and possessory action for restitution of possession (article 1198 and 1199). All of these protective measures need to be taken within a year of the disturbance or disseizing of possession (Article 1202).

Highly significant is the legal presumption established in article 1188 that the possessor of a right in rem is the lawful holder of that right, unless other presumptions exist based on registration, established before the possession. This provision can be used in many cases as an effective mechanism to prevent arbitrary dispossession: the possessor can challenge an eviction process, arguing that he or she is the presumptive owner of the land, based on the current possession. The other party will then have the burden to prove that the possessor is not the owner of the land.

153 To the five years mentioned in article 1215.2 should be added the five years referred in article 1215.1 (a); therefore it is mentioned a minimum period of 10 year of possession for adverse possession. 


\section{1- CONCLUSIONS}

It is possible to identify some progress in the Timorese land legislation approved since independence. The Constitution provide a number of clear rules regarding land rights, such as the equal rights to own land of men and women, and establishes limits to expropriation by the state. While the Civil Code can be criticized for being a legal transplant of the Portuguese Civil Code, and therefore not adapted to the Timorese reality, the provisions established for protection of possession and the possibility of obtaining land rights through adverse possession are important safeguards for the majority of the Timorese that do not have any formalized land rights. The Civil Code also initiated the legal recognition and regulation of customary land rights, which hopefully will be further acknowledged and developed. Decree-Law 27/2011, despite its limitations, represents an important first step in creating an open and transparent land claims process and a property registry.

Nevertheless, this legal analysis shows that there are still many gaps, inconsistencies, unrealistic requirements, informal procedures, and legislation without the necessary implementing regulations. The current legal framework exposes the population to all kinds of threats of eviction and loss of property. Those threats are caused by: a weak recognition of customary land rights; no recognition of land rights to long-term possessors of the land (despite the adverse possession established in the Timorese Civil Code); a broad definition of state land; the unclear status of land rights issued during previous administrations and the expiring of land use rights without possibility for renewing them; acquisition of land rights dependent on formalisms that are in practice very difficult if not impossible to follow (e.g., notary deeds), but their absence result in void acquisitions; and the leasing of land without clear knowledge regarding the ownership of the land. In addition, the few frail mechanisms of protection established in law are undermined by the current weak rule of law and deficient implementation of the existing provisions. And while the population in general is exposed to these threats, the most poor and disadvantaged are the ones at highest risk of being dispossessed of their land. The current land tenure scenario is also a strong deterrent for those investors that look for a clear and legal path to access land. ${ }^{154}$

The gaps, inconsistencies, unrealistic requirements, informal procedures and unregulated laws reveal difficulties in the law-making process. While legal transplants such as the Civil Code patch the unclear legal system, the Timorese formal land tenure system needs better and more adapted solutions. Further research focusing on the drafting process of land-related legislation could provide useful insights for better land tenure legislation in Timor-Leste.

\footnotetext{
154 An illustrative example the fact that Timor-Leste constantly ranks last $\left(189^{\text {th }}\right)$ in the International Finance Corporation (IFC) ranking Doing Business on the topic of 'registering property' (see http://www. doingbusiness.org/data/exploreeconomies/timor-leste).
} 


\section{2- REFERENCES}

\section{1- Books, Book Chapters, and Journal Articles}

ARD, Inc (2006). USAID-ARD Land Law Program II: Timor-Leste. Final Report. USAID

Bedner, Adriaan (forthcoming 2016). 'Indonesian land law: integration at last? And for whom?' in 'Land and Development in Indonesia: Searching for the People's Sovereignty'.

Brady, Cynthia; Timberman, David (2006). The Crisis in Timor-Leste: Causes Consequences and Options for Conflict Management and Mitigation. USAID

Canotilho, J. J. Gomes; Moreira, Vital (2007). Constituição da República Portuguesa Anotada, Volume I- $4^{a}$ edição revista. Coimbra Editora

Chesterman, Simon (2005). 'Rough Justice: Establishing the Rule of Law in Post-Conflict Territories' in Ohio state Journal on Dispute Resolution, 20 (1), 69-98

Commission for Reception, Truth and Reconciliation in East Timor (CAVR) (October 2005). Chega! Full report

Cotula, Lorenzo (2012). 'Securing Land Rights in Africa - Trends in National and International Law' in Fair Land Governance - How to Legalise Land Rights for Rural Development. Leiden University Press

Cotula, Lorenzo (2013). The Great African Grab? Agricultural Investments and the Global Food System. Zed Books Ltd. (Kindle version)

De Soto, Hernando (2000) The Mystery of Capital: Why Capitalism Triumphs in the West and Fails Everywhere Else. Basic Books

Dekker, Henri A. I. (2005). In pursuit of Land Tenure Security - Essays on Land Reform and Land Tenure. Pallas Publications

Delville, Philippe Lavigne (2010). 'Registering and Administering Customary Land Rights: Can We Deal with Complexity?' in Klaus Deininger, Clarissa Augustinus, Stig Enemark, Paul Munro-Faure (eds), Innovations in Land Rights Recognition, Administration, and Governance (World Bank Studies). World Bank 
Devereux, Annemarie (2015). Timor Leste's bill of rights: a preliminary history. ANU Press

D'Andrea, Claudia. (2003). The Customary Use of Natural Resources in Timor-Leste. Oxfam, German Technical Cooperation (GTZ) and the Timor-Leste Directorate of land and Property (DTP)

Ederington, L. Benjamin (1997). 'Property as a Natural Institution: the Separation of Property from Sovereignty in International Law' in American University International Law Review, 13(2), Article 1, 263-331

Fernandes, Luís A. Carvalho (2009). Lições de Direitos Reais - 6a Edição. Quid Juris Sociedade Editora, Lda

Figueiredo, Fernando Augusto de (2011). 'Timor na Viragem do Século XIX para o Século XX: Tipo de Colonização e os Seus Agentes' in Colóquio Timor: Missões Científicas e Antropologia Colonial, AHU, 24 and 25 of May 2011

Fitzpatrick, Daniel (2002). Land Claims in East Timor. Asia Pacific Press

Fitzpatrick, Daniel; McWilliam, Andrew; Barnes, Susana (2012). Property and Social Resilience in Times of Conflict: Land, Custom and Law in East Timor. Ashgate Pub Co Gorjão, Paulo (2004). 'O legado e as lições da Administração Transitória das Nações Unidas em Timor Leste' in Análise Social, vol. XXXVIII (169), 1043-1067

Guerreiro, Sara (2012). Colectânea De Direito Administrativo Timorense Com Comentários De Conteúdo Parte II - Actividade Administrativa Em Timor-Leste.

Provedoria dos Direitos Humanos e Programa das Nações Unidas para o Desenvolvimento (UNDP)

Haburas Foundation; Rede ba Rai (2013). Land Registration and Justice in Timor-Leste. Haburas Foundation and Rede ba Rai

Highlights of the 2010 Census Main Results in Timor-Leste. Ministry of Finance of Timor-Leste and United Nations Population Fund

IPAC - Institute for Policy Analysis of Conflict (2015). Justice at the Crossroads in TimorLeste. IPAC Report No. 22 
Jerónimo, Patrícia (2011). 'O Direito Timorense da Nacionalidade' in Scientia Ivridica, tomo LX, n. ${ }^{\circ} 325$

Jerónimo, Patrícia (2012). 'Os Direitos Fundamentais na Constituição da República Democrática de Timor-Leste e na jurisprudência do Tribunal de Recurso', in Estudos em homenagem ao Prof. Doutor Jorge Miranda, vol. 3, Almedina

JSMP - Judicial System Monitoring Programme (2014). Overview of the Justice Sector 2014 - JSMP Annual Report. JSMP

Kingsbury, Damien (2014). 'Democratic Consolidation in Timor-Leste: Achievements, Problems and Prospects' in Asian Journal of Political Science, 22 (2), 181-205

Krieger, Heike (1997). East Timor and the International Community: Basic Documents. Cambridge University Press

Leigh, John (2006). 'East Timor: A Summary of Land and Valuation Issues for a New and Developing Nation' in Expanding the Horizon: Re-Engineering the Profession through Innovations, World Valuation Congress XI, 9-11 May 2006, Kuala Lumpur

Lima, Pires de; Varela, Antunes (1997). Código Civil Anotado, Volume II - $4^{a}$ Edição Revista e Aumentada. Coimbra Editora

Lucas, Anton; Warren, Carol (2013). 'The Land, The Law and the People' in Anton Lucas and Carol Warren (eds), Land for the People: the State and Agrarian Conflict in Indonesia. Centre for International Studies Ohio University

Matadalan ba Rai - Haburas Foundation (2010). Community Voices on the Land: Results of the Consultation by Matadalan ba Rai. Matadalan ba Rai-Haburas Foundation, UNDP, Trocaire and Oxfam.

Mello, Maria Chaves de (2002). Dicionário Jurídico - Português-Inglês/Inglês-Português. Dinalivro

Morrow, Jonathan; White, Rachel (2002). 'The United Nations in Transitional East Timor: International Standards and the reality of Governance' in Australian Yearbook of International Law, 22, 1-46.

Narciso, Vanda; Henriques, Pedro; Tilman, Mário (2012). 'Land and Gender in Matrilineal Timor-Leste' in Actas do IX Colóquio Ibérico de Estudos Rurais 
Nixon, Rod (2009). 'Contracts, Land Tenure and Rural Development in Timor-Leste' in Justice for the Poor (World Bank) briefing note 51884, Volume 3, Issue 3

Otto, J. M. (2009). 'Rule of Law Promotion, Land Tenure and Poverty Alleviation: Questioning the Assumptions of Hernando de Soto' in Hague Journal on the Rule of Law, 1, 173-195

Penha, Rui (2012). Guia de Direitos Reais em Timor-Leste - Sumários desenvolvidos das aulas ministradas ao III Curso de Magistrados e Defensores Públicos no CFJ 2008-2009. Tribunal de Recurso

Plessis, Jean du, Leckie, Scott (2000). Housing, Property and Land Rights in East Timor: Proposals for an Effective Dispute Resolution and Claim Verification Mechanism. UN Habitat

Prata, Ana (2005). Dicionário Jurídico. 4th Edition, Revised and Augmented. Almedina Reerink, Gustaaf; Gelder, Jean-Louis van (2010). 'Land titling, perceived tenure security, and housing consolidation in the kampongs of Bandung, Indonesia' in Habitat International 34 (2010) 78-85

Reerink, Gustaaf (2011). Tenure Security for Indonesia's Urban Poor - A Socio-Legal Study on Land, Decentralization and the Rule of Law in Bandung. Leiden University Press

Sahin, Selver B. (2010). 'Timor-Leste in 2009 Marking Ten Years of Independence or Dependence on International "Assistance"?' in Southeast Asian Affairs, 2010(1), 344-364

Soares, Dionísio Babo (2004). 'Nahe Biti: The Philosophy and Process of Grassroots Reconciliation (and Justice) in East Timor' in The Asia Pacific Journal of Anthropology, $5(1), 15-33$

Sousa, Pedro Xavier de (2005). 'East Timor, Land Management - a Long Way to Go, But We Have Started' in FIG conference 2005, Bangkok

Taylor, John G. (1991). Indonesian's Forgotten War - The Hidden History of East Timor. Pluto Press Australia

Thomson, Nigel (2003). Towards Sunrise - East Timor, the United Nations and the Administration of Public and Private Abandoned Land in the Post-Conflict Environment. Unpublished master thesis form the University of Queensland 
Urresta, Edwin. (2004). Report on Research Findings, Policy Options and Recommendations for Compliance with the Constitution by Non-National Land Claimants of Pre-Existing Freehold Rights in East Timor. USAID

Urresta, Edwin; Nixon, Rod (2004a). Report on Research Findings and Policy Recommendations for A Legal Framework for Land Dispute Mediation. USAID.

Urresta, Edwin, Nixon, Rod (2004b). Report on Research Findings, Policy Options and Recommendations for A Law on Land Rights and Title Restitution. USAID

Vasconcelos, Pedro Bacelar de, (ed). (2011). Constituição Anotada da República Democrática de Timor-Leste. Direitos Humanos - Centro de Investigação Interdisciplinar, Escola de Direito da Universidade do Minho

Vieira, José Alberto C. (2008). Direitos Reais. Coimbra Editora

Williams, Charlotte C. (2009). 'Reaching Back to Move Forward: Using Adverse Possession to Resolve Land Conflicts in Timor-Leste'in Pacific Rim Law \& Policy Journal Association, 18 (3)

Yoder, Laura Suzzane Meitzner (2003). 'Custom and Conflict: The Uses and Limitations of Traditional Systems in Addressing Rural Land Disputes in East Timor' in regional workshop on Land Policy and Administration for pro-poor rural growth. Deutsche Gesellschaft Fur Techische Zusammenarbeit (GTZ, German Technical Cooperation), Direcção de Terras e Propriedades (DTP, Directorate of Land and Property) of East Timor Yoder, Laura Suzzane Meitzner (2005). Custom, Codification, Collaboration: Integrating the Legacies of Land and Forest Authorities in Oecusse Enclave, East Timor. Unpublished dissertation presented to the Faculty of the Graduate School of Yale University 


\section{2- Legislation (Timor-Leste) Constitution of the Democratic Republic of Timor-Leste}

Law 9/2002 on CitizenshipLaw 1/2003 on the Juridical Regime of Real Estate (Part 1 -

Ownership Over Immovable Property)

Law 4/2005 on Domestic Investment

Law 5/2005 on Foreign Investment

Law 12/2005 on Juridical Regime of Real Estate (Part II-Leasing between Individuals)

Law 10/2011 approving the Civil Code

Law 14/2011 on Private Investment

Decree-Law 2/2003 on Road Transport System

Decree-Law 3/2003 on Establishment of the Port Authority and on the Approval of the Bylaws

Decree-Law 1/2004 regulating the Citizenship Law

Decree-Law 3/2004 on Notaries

Decree-Law 19/2004 on Juridical Regime of Property: Official Allocation and Leasing of Private Property of the State

Decree-Law 1/2006 approving the Civil Procedure Code

Decree-Law 3/2006 approving the Regime of Occupation of Spaces and Areas of the Airports Public Domain

Decree-Law 20/2008 regulating the National Petroleum Authority

Decree-Law 32/2008 regulating the Administrative Procedure

Decree-Law 24/2009 approving the Juridical Regime of the Notary

Decree-Law 25/2009 on Notaries' Regulation

Decree-Law 6/2011 on Compensations for Eviction of State Property

Decree-Law 27/2011 - Regime to Regulate Ownership of Immovable Property in Undisputed Cases 
Decree-Law 4/2014 regulating the Pre-Deconcentration

Decree-Law 06/2015 establishing the Organic Law of the VI Constitutional Government

Decree-Law 25/2015 establishing the Organic Law of the Ministry of Justice Ministerial-Decree 1/2006 regulating the Juridical Regime of the Private Domain of the State

Ministerial-Decree 035/2009 establishing the Organic Law of the National Directorate of Land, Property and Cadastral Services

Ministerial-Decree 16/2011 on Cadastral Survey

Ministerial-Decree 23/2011 on Conversion of Land Declarations into Land Registry

\section{3- UNTAET Legislation}

UNTAET Regulation No. 1999/1 on the Powers of the Transitory Administration of TimorLeste

UNTAET Regulation No. 2000/27 establishing the Temporary Prohibition of Transactions in Land in East Timor by Indonesian Citizens not Habitually Resident in East Timor and by Indonesian Corporations

\section{4- Portuguese Legislation}

Constitution of the Portuguese Republic (1976)

Civil Code of 1867, applicable Overseas through a Decree of 18/11/1869

Administrative Rule (Portaria) No.193 of 27/07/1914, regulating the Alvará Indigena (Indigenous land titles)

Decree-Law 23052 of 23/09/1933 on Economical Housing

Decree 46602 of 20/10/1965 on Economical Housing

Civil Code of 1966.

Administrative Rule (Portaria) No. 3848 of 5/02/1966 on Economical Housing.

Legislative Diploma No. 865 of 25 September 1971, regulating the Occupation and Concession of Land in the Province of Timor

Decree-Law 195-A/76 on Conversion of Enfiteuse (or Aforamento) into Ownership Rights

Law 108/97 on Conversion of Enfiteuse (or Aforamento) into Ownership Rights 


\section{5- Indonesian Legislation}

Law No. 62/1958 establishing the Indonesian Nationality Law

Law No. 5/1960 approving the Basic Agrarian Law Undang-Undang Pokok-Pokok Agraria)

Law No. 56/1960 (Peraturan Pemerintah pengganti Undang-undang No. 56/1960)

Law 20/1961 on Revocation of Rights of Land and the Objects Over The Land (Pencabutan Hak-Hak Atas Tanah Dan Benda-Benda Yang Ada Di Atasnya)

Law No. 5/1967on Principles of Foresty (Ketentuan-Ketentuan Pokok Kehutanan)

Law 41/1999 on Indonesian Policy On Forest Management (Tentang Kehutanan)

Law No. 12/2006 - Citizenship of the Republic of Indonesia

Regulation No. 18/1991 on Provisions on The Conversion of Land Rights in the Province of East Timor in Accordance With the Basic Agrarian Law

Government Regulation No. 34/1992

Government Regulation No. 24/1997

Presidential Decree No. 32/1990

\section{6- Legislation from Other Countries}

Constitution of the Federal Republic of Brazil

Constitution of the Republic of Mozambique

Brazilian Civil Code

French Civil Code

Spanish Law 33/2003 regarding state property

\section{7- Decisions of the Timorese Courts}

Court of Appeal (no number) of 16/07/2008 (Appeal of the process 03/Cível/2002/TD.DIL)

Court of Appeal No 56/2003 of 30/03/2009

Court of Appeal No. 31/2003 of 13/05/2009

Court of Appeal No 56/2004 of 01/06/2009

Court of Appeal No. 06/2003 of 16/07/2009

Court of Appeal No. 07/2009 of 02/02/2010 
Court of Appeal No. 23/01 of 10/03/2010;

Court of Appeal No. 12/2009 of 10/03/2010

Court of Appeal No 02/PC/2010/TR of 19/03/2010

Court of Appeal No. 57/2003 of 04/06/2010

Court of Appeal No. 05/Cível/Apelação/2012/TR of 01/06/2012

Court of Appeal No. 08/Cível/2013/TR of 29/05/2013

Court of Appeal No 14/Cível/2013/TR of 30/07/2013

Court of Appeal No 16/Cível/Agravo/2011/TR of 25/09/2013

Dili District Court No. 42/Cível/2009/TD.DIL of 11.10.2009

Dili District Court No. 58/Cível/2011/TD.DIL of 25/10/2011

Dili District Court No. 42/Cível/2009/TD.DIL of 10.11.2009

\section{8- Decisions of the Portuguese Courts}

Supremo Tribunal de Justiça No. JSTJ00041092

Supremo Tribunal de Justiça No. JSTJ00007135

Tribunal da Relação de Coimbra No. 358/06.8TBSRE.C2

Tribunal da Relação de Lisboa No. JTRL00021960

Tribunal da Relação de Lisboa No. JTRL00001437

Tribunal da Relação de Lisboa No. JTRL00001026

\section{9- Decisions of Indonesian Courts}

- Indonesian Constitutional Court No. 35/PUU-X/2012

\subsection{0- Websites}

http://btimor.iict.pt/

http://www.dgsi.pt/

http://www.doingbusiness.org/data/exploreeconomies/timor-leste

http://jornal.gov.tl/

http://jornal.gov.tl/lawsTL/index-e.htm

http://reliefweb.int/report/timor-leste/untaet-daily-briefing-25-oct-2000 


\subsection{1- Newspaper Articles and Media Releases}

Business Timor 28/12/2012 - Governu Fo Kompesasaun Ba Uma Kain 11 Aitarak-Laran http://www.jornalbisnistimor.com/lalenok-sidade-dili/208-governu-fo-kompesasaun-bauma-kain-11-aitarak-laran 


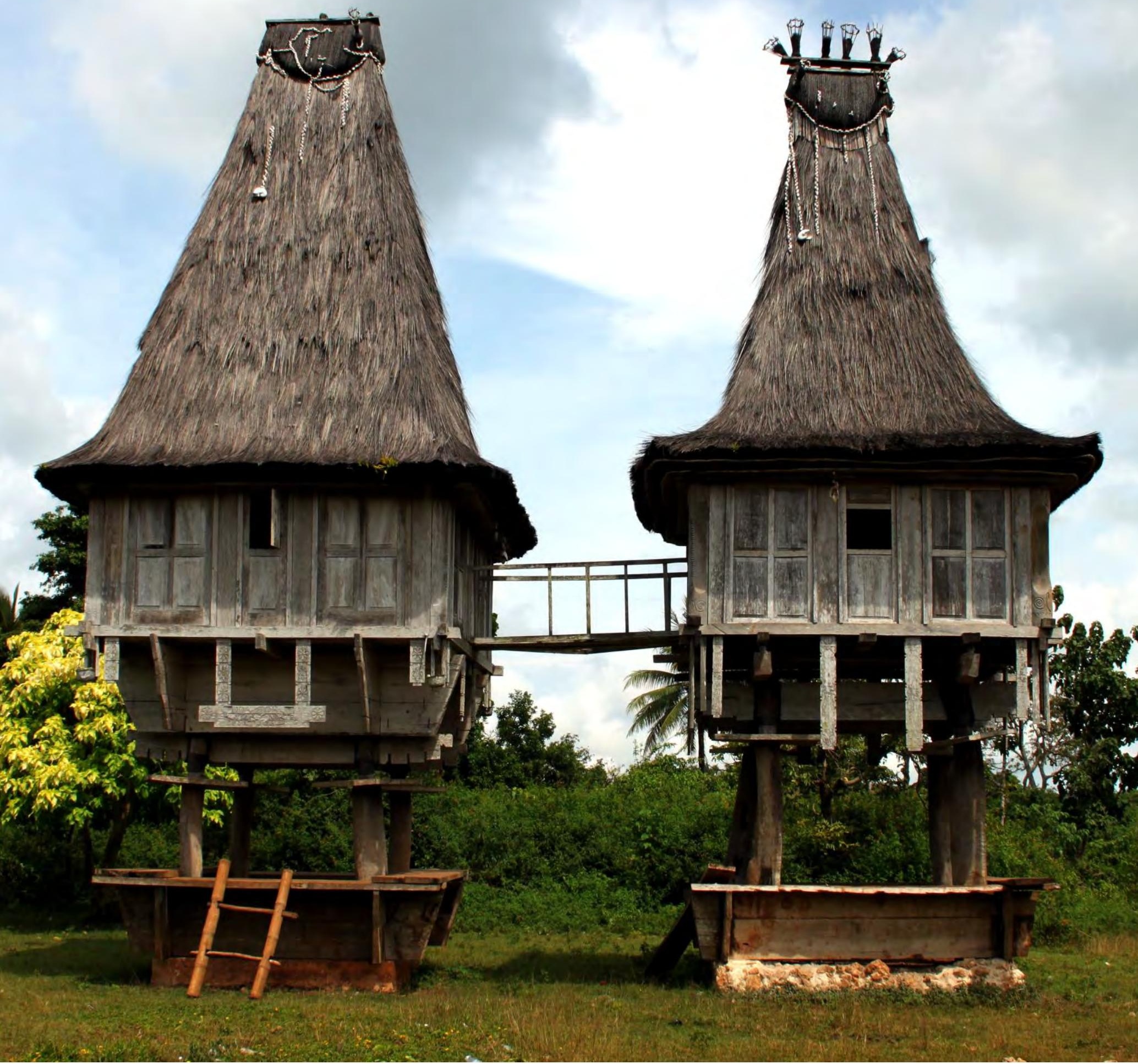

